Review

\title{
Impact of Environmental Factors on the Regulation of Cyanotoxin Production
}

\author{
Thangavelu Boopathi and Jang-Seu Ki *
}

Department of Life Science, Sangmyung University, Seoul 110-743, Korea;

E-Mail: iamboopathy@gmail.com

* Author to whom correspondence should be addressed; E-Mail: kijs@smu.ac.kr; Tel.: +82-2-2287-5449; Fax: +82-2-2287-0070.

Received: 30 April 2014; in revised form: 6 June 2014 / Accepted: 17 June 2014 /

Published: 25 June 2014

\begin{abstract}
Cyanobacteria are capable of thriving in almost all environments. Recent changes in climatic conditions due to increased human activities favor the occurrence and severity of harmful cyanobacterial bloom all over the world. Knowledge of the regulation of cyanotoxins by the various environmental factors is essential for effective management of toxic cyanobacterial bloom. In recent years, progress in the field of molecular mechanisms involved in cyanotoxin production has paved the way for assessing the role of various factors on the cyanotoxin production. In this review, we present an overview of the influence of various environmental factors on the production of major group of cyanotoxins, including microcystins, nodularin, cylindrospermopsin, anatoxins and saxitoxins.
\end{abstract}

Keywords: cyanotoxin; microcystins; nodularin; cylindrospermopsin; anatoxins and saxitoxins

\section{Introduction}

Cyanobacteria are a group of oxygenic photoautotrophic Gram negative bacteria which are morphologically diverse and ubiquitous in nature [1,2]. They are also known as one of the primitive oxygen-producing organisms on Earth with the fossil records of $\sim 3.5$ billion years [3]. Cyanobacteria capable of fixing atmospheric nitrogen, solubilize phosphorous and sequester iron which gives them greater adaptability to diverse terrestrial and aquatic environments with various nutrient levels [4]. The occurrence of cyanobacterial bloom in fresh water sources is considered as an environmental 
problem worldwide. In particular, toxic cyanobacterial blooms in freshwater systems around the world have increased in frequency and severity [1,5]. However, nutrient enrichment of both freshwater and marine systems by anthropogenic activities promoted the growth of cyanobacteria, and increased the incidence of harmful algal blooms [1,6-8].

Cyanotoxins are diverse group of secondary metabolites produced by various genera of cyanobacteria which are toxic to most of the eukaryotic organisms including algae, plants, cattle and humans (Table 1) [4,9]. Many bloom-forming cyanobacteria are known to produce various toxins which have drastic impact on the ecosystem and its functions [9,10]. In addition, cyanobacterial blooms create a threat to drinking and recreational water by producing harmful toxins and stinking compounds [11]. In addition, the bloom formation can cause hypoxia and disrupt food webs in the ecosystem [11].

Cyanotoxins are broadly classified based on their modes of action in invertebrates such as hepatotoxins, neurotoxin, and dermatotoxins (aplysiatoxin, lyngbyatoxin-a). This review mainly emphases on the regulation of major cyanobacterial hepatotoxins and neurotoxins. Cyanobacterial hepatotoxins include microcystin (MCs), nodularin (NODs) and cylindrospermopsin (CYN). However, the latter one has both cytotoxic and neurotoxic potentials $[9,12,13]$. In addition, anatoxins (ATXs) and saxitoxins (STXs) are neurotoxins which are produced by various cyanobacterial species [14]. Based on their chemical composition, cyanotoxins can be grouped in to cyclic peptides (MCs and NODs), alkaloids (ATXs, STXs, CYN, aplysiatoxin, lyngbiatoxin-a) and lipopolysaccharides [13,15]. Most of the cyanotoxins are not extracellular, withf exception of CYN, but when cyanobacterial cells lyses, these toxins can be released at high concentrations into the environment [12]. Further, various cyanotoxins can also exhibit allelopathic properties that may have adverse effects on surrounding communities include other bacteria and phytoplankton [16,17].

The current scenario in global climate change and increased $\mathrm{CO}_{2}$ concentrations can greatly influence the microbial communities in various environments, particularly in aquatic ecosystems $[10,18]$. The cyanobacterial community may also be altered by various physical/chemical factors, including change in environmental conditions such as climate change and it is essential to understand and predict the responses of these communities [7,19]. After comparing 42 years of incidence data of cyanobacteria and other eukaryotic phytoplankton from the small subalpine Castle Lake in northern California, Park et al. [20] found that the cyanobacterial biovolume was increased with increasing water temperatures. However, it has been shown that the diatoms and other phytoplankton groups did not reveal any significant change with summer water temperatures [20]. In a survey of 143 lakes along a latitudinal transect ranging from subarctic Europe to southern South America with varying trophic states revealed the significant increase in cyanobacterial biomass with increasing temperature whereas total phytoplanktonic biomass remain unchanged [21]. However, the factors involved in the increase of toxin production and increased occurrence of toxin-producing cyanobacterial species are still unclear. When polar cyanobacterial mat samples were grown at increased temperatures favored the growth of toxin producing genera, even at nutrient limiting conditions [18]. Globally, the trend of increased growth of toxin-producing Microcystis spp. has been observed in the recent years [1,22]. 
Table 1. Nature of cyanobacterial toxins (see text for further details [15,23-25]).

\begin{tabular}{|c|c|c|c|c|}
\hline Toxins & Variants & Toxin producing cyanobacterial genera & Toxic mechanism & Health effects \\
\hline Microcystin & Over 85 variants & $\begin{array}{l}\text { Anabaena, Anabaenopsis, } \\
\text { Aphanizomenon, Merismopedia, } \\
\text { Microcystis, Oscillatoria, Phormidium, } \\
\text { Synechococcus and Planktothrix }\end{array}$ & $\begin{array}{l}\text { Hepatotoxic, inhibits eukaryotic } \\
\text { protein phosphatases }\end{array}$ & $\begin{array}{l}\text { Gastrointestinal, liver inflammation, } \\
\text { and hemorrhage and liver } \\
\text { failure leading to death, } \\
\text { pneumonia, dermatitis }\end{array}$ \\
\hline Nodularin & 8 variants & Nodularia and Nostoc & $\begin{array}{l}\text { Hepatotoxic, inhibits eukaryotic } \\
\text { protein phosphatases }\end{array}$ & $\begin{array}{l}\text { Gastrointestinal, liver inflammation, } \\
\text { and hemorrhage and liver } \\
\text { failure leading to death, } \\
\text { pneumonia, dermatitis }\end{array}$ \\
\hline Cylindrospermopsin & $\begin{array}{l}3 \text { variants, Cylindrospermopsin } \\
\text { 7-epicylindrospermopsin } \\
\text { 7-deoxycylindrospermopsin }\end{array}$ & $\begin{array}{l}\text { Cylindrospermopsis, Anabaena, } \\
\text { Aphanizomenon, Oscillatoria, Raphidiopsis, } \\
\text { Umezakia and Sphaerospermopsis }\end{array}$ & $\begin{array}{l}\text { Hepatotoxic, cytotoxic, neurotoxic; } \\
\text { inhibition of glutathione synthesis, } \\
\text { protein synthesis and } \\
\text { cytochrome P450 }\end{array}$ & $\begin{array}{l}\text { Gastrointestinal, liver inflammation } \\
\text { and hemorrhage, } \\
\text { pneumonia, dermatitis }\end{array}$ \\
\hline Anatoxin-a & $\begin{array}{l}3 \text { variants, Anatoxin-a, } \\
\text { homoanatoxin-a } \\
\text { Anatoxin-a(s) }\end{array}$ & Anabaena, Aphanizomenon and Oscillatoria & $\begin{array}{l}\text { Neurotoxic, mimics the } \\
\text { neurotransmitter acetylcholine }\end{array}$ & $\begin{array}{l}\text { Tingling, burning, numbness, } \\
\text { drowsiness, incoherent speech, } \\
\text { respiratory paralysis leading to death }\end{array}$ \\
\hline Saxitoxin & 20 variants & $\begin{array}{l}\text { Anabaena Aphanizomenon, } \\
\text { Cylindrospermopsis, Lyngbya, Planktothrix, } \\
\text { Raphidiopsis and Scytonema }\end{array}$ & $\begin{array}{l}\text { Neurotoxic, blocks voltage-gated } \\
\mathrm{Na}^{+} \text {channels }\end{array}$ & $\begin{array}{l}\text { Tingling, burning, numbness, } \\
\text { drowsiness, incoherent speech, } \\
\text { respiratory paralysis leading to death }\end{array}$ \\
\hline
\end{tabular}


Moreover, toxin producing cyanobacteria not only withstand various environmental stresses but also produce elevated levels of toxins under stressful conditions [26,27]. Cyanobacteria blooms generally comprised of various species including toxin and non-toxin producers as well as nitrogen and non-nitrogen-fixers [27]. The environmental factors such as temperature, light intensity, $\mathrm{pH}$, nutrients, salinity, ultraviolet radiation, wind, trace metals and environmental pollutants can influence the growth of the cyanobacterial species and their cyanotoxin production [14]. Therefore, understanding the influence of environmental changes on cyanobacterial bloom formation and toxin production is crucial for the management of toxic cyanobacterial bloom. In this review, we summarize the effect of regulatory molecules and influence of various environmental factors on the biosynthesis of five major cyanotoxin groups. Although the studies pertaining to the influence of environmental factors on the regulation of cyanotoxin production at molecular level are scarce, this review attempts to summarize the available reports.

\section{Microcystins (MCs) \& Nodularins (NODs)}

The hepatotoxins MCs and NODs are found to be similar with regard to structure and mode of action, and are hence discussed together in this section. These toxins were found to target liver and brain [28,29] and inhibit the protein phosphatase [23] that will result in the accumulation of phosphorylated proteins in the liver which triggers cell death through necrosis and hemorrhage [15,30]. Although the toxicity was considered based on the mixture of toxic variants of the above toxins, MC-LR (leucine and arginine variant) and NOD-R (arginine variant) are being referred as standards and the lethal dose 50 (LD50) of MC-LR is 25 to $150 \mu \mathrm{g} / \mathrm{kg}$ and LD50 for NOD-R is 50 to $150 \mu \mathrm{g} / \mathrm{kg}$ [23]. The mechanism behind the toxicity of MC-LR was studied recently in detail by [31]. Their study indicated the induction of protein kinase and phosphorylation of proteins associated with microfilaments in human liver cell line HL 7702 by MC-LR [31]. MCs were also reported as having tumor inducing property [23]. Recently, MCs were isolated from Planktothrix rubescens Strain No80 which shown to inhibit protein phosphatases at nano molar range [32]. While MCs are reported in varied regions like Asia, Europe, North Africa, North America and Scandinavian countries, NODs appear to be confined to Australia, New Zealand and the Baltic Sea [23,33,34]; since MCs have been produced by so many species of cyanobacteria (Microcystis, Oscillatoria, Aphanizomenon, Merismopedia, Nostoc, Anabaena, Phormidium, Planktothrix and Anabaenopsis) and production of NODs were reported only with Nodularia spumigena, Nodularia sphaerocarpa and also with Nostoc species recently [13-15,35-37].

\subsection{Synthesis and Regulation}

MCs and NODs are cyclic heptapeptides and pentapeptides which possess the unusual Adda amino acid (3-amino-9-methoxy- 2, 6, 8-trimethyl-10-phenyl-4, 6-dienoic acid) with diene conjugate respectively (Figure 1A). They are produced non-ribosomally from $m c y$ and $n d a$ gene clusters respectively (Figure 1B). To date, more than 85 variants of MCs were identified from various cyanobacterial species [14,33]. Biosynthesis of MCs, NOD and other cyanobacterial toxins and their toxic nature was reviewed by Pearson et al. [15]. 
Figure 1. (A) Shows the structure of Microcystin-LR and Nodularin; (B) Showing the gene cluster $m c y$ encoding Microcystin and $n d a$ cluster which encodes Nodularin; possible derivation of $n d a$ from $m c y$ region is also given. Promoter regions were highlighted with bold lines in both $m c y$ and $n d a$ cluster. See text for further details [38].

A
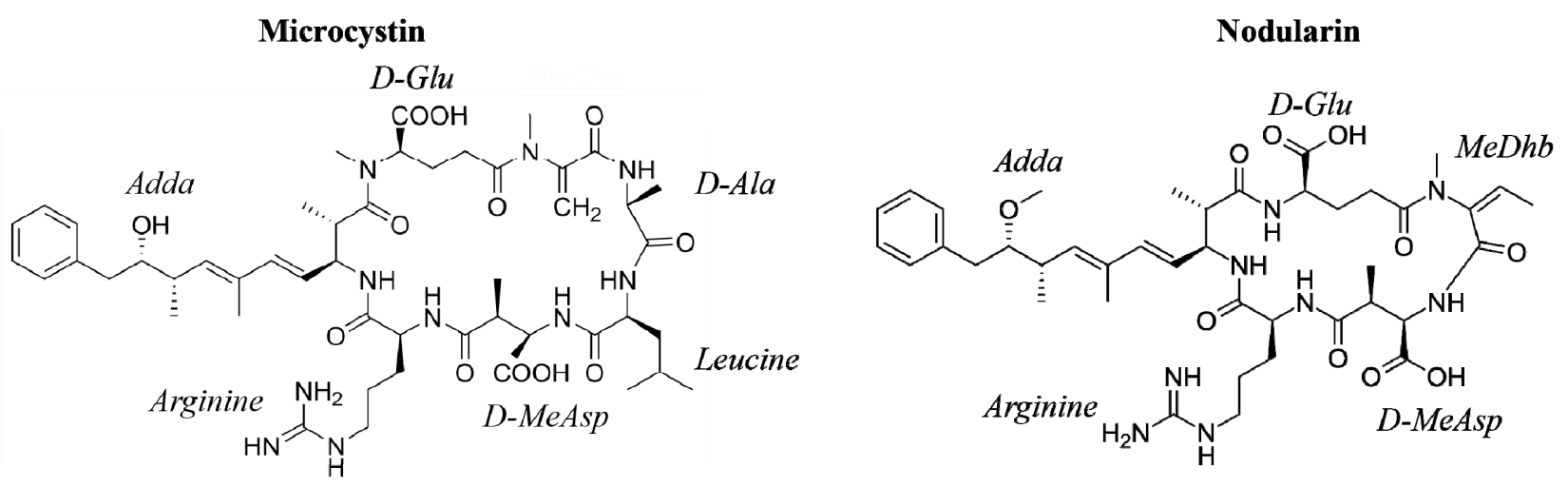

B

Microcystin (mcy) gene cluster, $55 \mathrm{~kb}$.

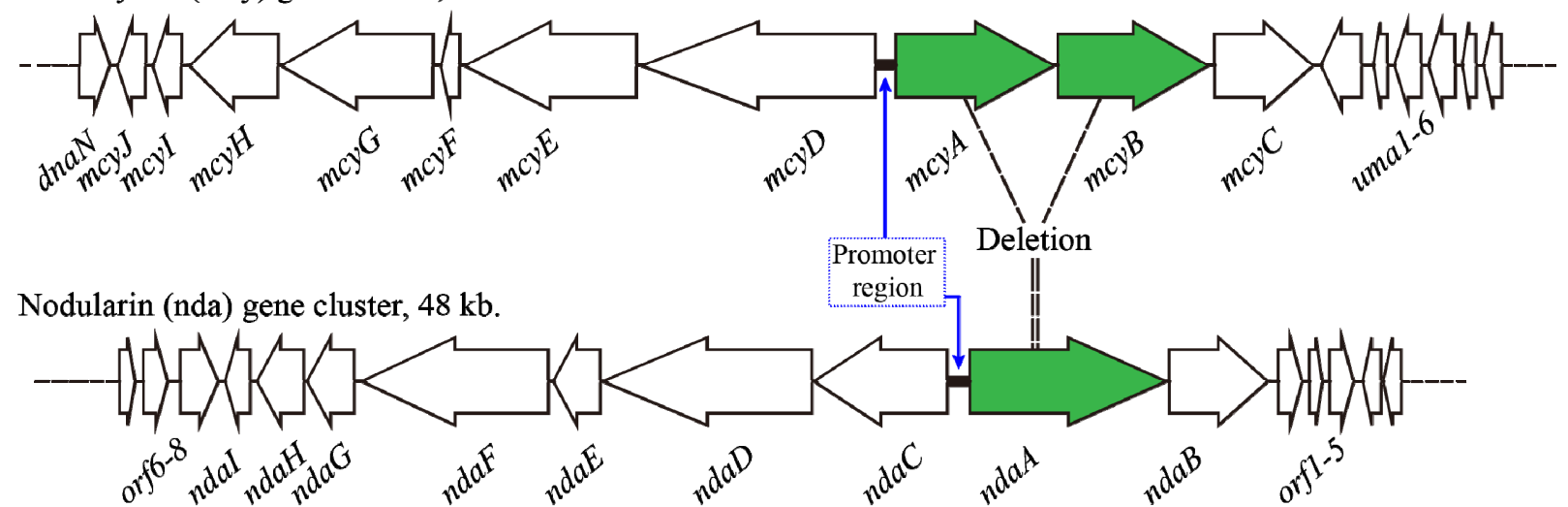

MCs are synthesized by enzyme complexes including non-ribosomal peptide synthetase (NRPS) and polyketide synthase (PKS) [14]. In M. aeruginosa PCC7806, mcy (mcyABCDEFGHIJ) gene cluster $(55 \mathrm{~kb})$ contains two polycistronic operons with 10 genes enclosing $m c y A B C$ and $m c y D E F G H I J$ and a bidirectional promoter has been observed between $m c y A$ and $m c y D$ (Figure 1B) [13]. Detailed study has been done on $m c y$ regulation [12,15,39]. $m c y$ is regulated by a complex network system including limitations of nutrients, dual transcriptional regulator and factors inducing stress (light, etc.). These factors are involved in the regulation of MCs synthesis. A study by Wood et al. [40] reported that significant changes were observed with $m c y E$ transcript levels in a Microcystis bloom. Further, their study suggested the influence of environmental factors in toxin production [40]. Organization of the ORFs of the mcy cluster is not the same between the following organisms: Microcystis, Anabaena and Planktothrix [14]. As hypothesized by Rouhiainen et al. [41], mcy of Microcystis and Planktothrix might be derived from mcy of Anabaena along with some gene reorganization events. In addition, Christiansen et al. suggested that [42] $m c y$ cluster could be derived from $n d a$ cluster by some gene additions. However, some genes of the toxin gene cluster might be conserved throughout the evolution. 


\subsection{Environmental Factors Regulating MCs Synthesis}

Biosynthetic gene cluster of microcystin synthetase $m c y$ has been shown with binding sites for the following transcriptional regulators namely, NtcA (nitrogen responsive regulatory protein), FurA (a ferric uptake regulator) and RcaA (redox-active photoreceptor protein) [39,43-45]. NtcA is a dual transcriptional regulator; based on the binding site it may up/down regulate the candidate genes. The consensus sequence for NtcA binding is 5' GTA N8 TAC 3' with highly conserved bases at the end $\sim 22 \mathrm{bp}$ is found at the upstream of the -10 region [46,47]. This recognition sequence is surrounded by $\mathrm{A} / \mathrm{T}$ bp and the dual regulation of NtcA is based on the number of the intervening spacer nucleotides [48]. New binding sites for NtcA concerning the promoter of $m c y$ were also studied in detail [49]. Nitrogen limitation was shown to increase the production of MC by enhancing the transcription of $m c y$. As reviewed by Ermilova and Forchhammer, [50] under N-limitation, cellular levels of 2-oxoglutarate (2-OG) increased and PipX $\left(\mathrm{P}_{\mathrm{II}}\right.$-interacting protein $\left.\mathrm{X}\right)$ was released from the signal transduction protein $\mathrm{P}_{\mathrm{II}}$ and readily available to bind with $\mathrm{NtcA}$ and 2-OG to form the complex. This complex helps in the binding of NtcA towards its target sequences to regulate gene expression. However, with enough N, a complex formed between PipX and $\mathrm{P}_{\text {II }}$ which cannot activate NtcA [50]. Ginn et al. [44] also confirmed that the expression of $n t c A$ was more ( $\sim 4$ fold) under $\mathrm{N}$-limitation than with excess $\mathrm{N}$ in $M$. aeruginosa PCC7806 which is a microcystin producer and in the same study induction of $m c y B$ was also reported under N-limitation. Kuniyoshi et al. [49] demonstrated the binding affinity between NtcA and promoter of $m c y$ cluster ( $m c y D A, m c y E$ and $m c y H$ ) by electrophoretic mobility shift assay (EMSA); they also confirmed that this binding affinity between NtcA and $m c y A$ promoter was further promoted 2.5 fold with increased 2-OG at $25 \mu \mathrm{mol}$ photons $\mathrm{m}^{-2} \cdot \mathrm{s}^{-1}$. It was confirmed that the 2-OG also acts as the signaling molecule to sense the balance between $\mathrm{C}$ and $\mathrm{N}$ and thus regulates $\mathrm{MC}$ production [51]. Negative regulation of $\mathrm{NtcA}$ was also suggested on $m c y A B C$ promoter, since one of the consensus sequences of NtcA showed similarity with the binding site of gor repressor in Anabaena PCC7120 [52].

Reports regarding relations between nitrate concentrations and MC production have provided contradictory results as described below, and this may be due to methanol extraction in which protein-bound toxin is not being measured. Although we mentioned above that N-limitation was found to have positive impact on MC production [53], in the unicellular, non-nitrogen-fixing cyanobacterial species, more MC production was reported with increased nitrate concentration [54-56]. In M. aeruginosa PCC7806, elevated nitrate concentrations could only increase the growth rate and did not change MC production [57]. Tonk et al. [58] studied the effect of $\mathrm{N}$ availability on MC production; when they added Leucin ( $\mathrm{N}$ poor amino acid), microcystin LR synthesis increased and microcystin-RR increased when they added the arginine ( $\mathrm{N}$ rich amino acid) in Planktothrix agardhii strain 126/3 [58]. It was also shown that $\mathrm{CO}_{2}$ and nitrogen enrichment was the main reason for increased production of N-rich microcystin-RR variants in Microcystis blooms [59]. Proteomics studies of toxic and nontoxic M. aeruginosa strains revealed that genes involved in carbon dioxide-concentrating mechanism (CCM) $(C \mathrm{cmK} 3$ and $C \mathrm{cmL})$, genes involved in nitrogen uptake and metabolism $\left(P_{I I}\right.$ and $\left.N r t A\right)$ and the redox balance regulating protein coding genes $(N d h K$ and $\operatorname{Tr} x M)$ showed differential expression pattern and they seem to play a vital role in maintaining C:N in the cell which can modulate MC production [39]. These studies also indicated the effect of MCs in the proteome of M. aeruginosa. MCs producing cyanobacterial strains were found to have more adaptation ability under unfavorable conditions than 
the mutant non-toxin producers [60,61]. Recently, induction of $\mathrm{MC}$ production in response to increased nitrogen in $M$. aeruginosa has been reported [62]. Community structure of cyanobacteria which consists of MC-RR producing $M$. aeruginosa, MC-LA producing $M$. wesenbergii and MC-YR producing Aphanizomenon flos-aquae was influenced by environmental factors and especially forms of N-source, and this will determine the toxic nature of the bloom [63].

Research by Ding et al. [64] strongly suggested that UVB radiation supports the growth of MC producing cyanobacterial strains. They also indicated that non-MC producers are vulnerable to radiation when compared with MC producers [64]. Researchers showed that light also plays an essential role in MC production; differences in light intensity could change the transcription start sight of $m c y A$ [43,65] and this was not observed with various nitrogen concentrations. Sevilla et al. [57] suggested that light was found to have more impact on MC production than nitrogen. In P. agardhii, increased light intensity altered the ratio between MC variants; production of microcystin-DeLR was greater while the production of microcystin-DeRR decreased with more light $\sim 60 \mu \mathrm{mol} \mathrm{m} \mathrm{m}^{-2} \cdot \mathrm{s}^{-1}$, among them microcystin-DeLR was found to be more toxic than microcystin-DeRR [66]. Initial induction in transcription of $m c y D$ was observed under more light intensity [30,67] $\mu$ mol photons $\mathrm{m}^{-2} \cdot \mathrm{s}^{-1}$ [68] and $30 \mu \mathrm{mol}$ photons $\mathrm{m}^{-2} \cdot \mathrm{s}^{-1}[65]$ and reduction was also reported. High light intensity shows an advantage in growth rate and toxin production in microcystin-producing M. aeruginosa PCC7806 and their work also confirmed that MCs protect the cells against photo oxidation and changes in the nutrition did not show any changes in MC production under high light [69]. Although the relationship between oxidative stress and MC is not clearly understood, induction of $m c y$ transcription, binding of MC with $\mathrm{RbcL}$ and sensitivity of $m c y$ mutants revealed that MC might have a protective role against high light intensity and oxidative stress conditions [26]. Prevention of chlorosis was observed with MC synthesis under light stress and production of pigments (chlorophyll a, b-carotene, zeaxanthin and echinenone) was under greater light stress in wild type of Microcystis aeruginosa when compared with mutant MC non producer cells. MC was found to protect the cells by binding with the large subunit of RuBisCo $(r b c L)$, when oxidative stress induced by high light intensity [12]. Reports discussed above strongly suggested the vital role of NtcA in the regulation of $m c y$ and $r b c L$, carbon cycling and in oxidative stress. The relation between photosynthesis and MC production was studied in detail [68,70]; it shows that cells need active photosynthesis to produce more toxins.

There are discrepancies in studies associated with FurA and MC production, although the binding site of FurA has been reported in $m c y$ promoter. As per Alexova et al. [39,45], reduction in transcription of $m c y A$ was seen while MCs production was induced due to iron starvation, although FurA usually negatively regulates the target genes in the presence of ferrous iron. Increased MC production and $m c y D$ transcription was observed under iron limitation [71]; but a study by Utkilen and Gjølme, [54] indicated that more MCs were produced with more available iron. These contradictions may be due to the methodology they used in their study. By considering all the factors mentioned above, growth rate of cyanobacterial strains might influence the production of MCs and thus environmental factors might play a vital role in the production of these toxins. 


\subsection{Environmental Regulation of Nodularin}

Regarding NOD synthesis and regulation, NOD was also synthesized by NRPS and PKS enzymes. $n d a$ cluster consists of nine ORFs ( $n d a A$-ndaI) with a bidirectional regulatory promoter; $n d a A B$, ORF1, ORF2 and $n d a C$ has been transcribed in two polycistronic mRNAs (Figure 1B) [38]. As reviewed by Pearson et al. [15], ORF1, ORF2 and ORF3 were found to be present at the downstream of $n d a A B$ genes which are associated with $n d a$ cluster by encoding a putative transposase, putative high light-inducible chlorophyll-binding protein and putative heat shock repressor protein respectively; they also suggested that ORF2 might be associated with NOD synthesis under light stress and ORF3 might play a role in transcriptional regulation of $n d a$ cluster under heat stress. The nda cluster is predicted to be derived from the region between $m c y A-A 2$ and $m c y B-C 2$ domain by deletion (Figure 1B) [34,72]. To date, eight variants of NOD have been reported [73].

Nodularia spumigena blooms were reported predominately under higher phosphorus, moderate salt concentrations and low N:P ratios [73]. Recent reports concluded that NOD production is being controlled by three major factors including biological nitrogen fixation, light stress and phosphate limitation (see below). Occurrence of the binding site of NtcA (nitrogen responsive regulatory protein) in the upstream region of $n d a$ in N. spumigena NSOR10 and N. spumigena CCY9414, and also in the heterocyst forming genes of Anabaena PCC7120 indicated the role of nitrogen fixation in nodularin synthesis [74]; hetR gene from Nodularia and Nostoc species were found to be regulated by NtcA [34]. Jonasson et al. [75] reported that $n d a$ cluster was inducible with phosphate starvation and down-regulated by ammonia supplementation, but it did not change intracellular/extracellular concentrations of nodularin; ammonia supplementation also down-regulates the transcription of ndaF and nifH genes; reduction in nitrogen fixation was reported in $N$. spumigena with ammonia [75,76]. These results confirmed the essentiality of nitrogen fixation in NOD production. However, it purely depends on environmental factors, because more production of NOD was observed in aquatic nitrogen fixing species, N. spumigena, but very low production of NOD has been reported from terrestrial Nostoc spp. [72]. Differences in carbon and nitrogen fixation rates might be the cause for this change in NOD production as reported by [77]. Light stress does play a vital role in NOD synthesis, ORF2 (co-transcribed with nda cluster) which codes for high light inducible chlorophyll-binding protein (HLIP) is associated with light stress in N. spumigena NSOR10 and N. spumigena CCY9414 [38,78]. NOD synthesis was enhanced by elevated temperature $\left(25-28{ }^{\circ} \mathrm{C}\right)$, more light $\left(45-155 \mu \mathrm{mol}\right.$ photons $\left.\mathrm{m}^{-2} \cdot \mathrm{s}^{-1}\right)$ and high phosphate concentration $\left(200-5500 \mu \mathrm{g} \cdot \mathrm{L}^{-1}\right)$ while high salinity and high inorganic nitrogen concentrations were found to inhibit NOD production [79]. All these studies also suggested that combination of environmental factors plays a major role in NOD production.

\section{Cylindrospermopsin}

\subsection{Characteristics}

Cylindrospermopsin (CYN) is an alkaloid toxin containing guanidiono and sulfate groups produced by several filamentous cyanobacteria including Cylindrospermopsis raciborskii, Anabaena bergii, Aphanizomenon ovalisporum, Aph. flos-aquae, Oscillatoria sp. PCC6506, Raphidiopsis curvata, Sphaerospermopsis aphanizomenoides and Umezakia natans [12,13,80-84]. Among CYN producing 
cyanobacteria, C. raciborskii is the well-known CYN producing cyanobacteria which contains both toxin producing and non-toxin producing strains $[80,85,86]$. However, in recent years, CYN has also been reported from temperate countries, such as Germany and France and also from boreal environments [87,88]. It is also shown that CYNs have been accumulated in the environment over time [89]. CYN production is similar to the synthesis of MCs, where toxin synthesis is regulated by genes coding for polyketide synthase and peptide synthetase [80].

\subsection{Structure and Toxicity}

CYN, is an alkaloid (415 Da) containing a tricyclic guanidine unit and a uracil moiety which is mainly involved in toxicity [90]. In addition, two other variants of this toxin have also been identified; 7-epicylindrospermopsin which differs only by the orientation of the hydroxyl group close to the uracil moiety [91], and deoxycylindrospermopsin, which is characterized by a missing oxygen atom related to the initial hydroxyl group close to uracil moiety (Figure 2A) [92]. However, deoxycylindrospermopsin appears to be non-toxic [93]. The zwitterionic structure of CYN makes it a highly polar compound and thus highly water-soluble [94]. Chiswell et al. [94] reported that CYN has poor stability in crude algal extract in which $90 \%$ of the toxin has been degraded within 3 days when exposed to sunlight. In contrast, CYN showed more than 10 days of half-life in high purity water which indicates that $\mathrm{pH}$ and temperature may play a major role in the degradation of toxin [94]. In contrast, Wormer et al. [95] reported that the CYN was not degraded by the naturally occurring microbial communities even after 40 days and this may lead to accumulation of CYN in water bodies and increase the risk.

Figure 2. (A) Showing the structure of cylindrospermopsin and its variants; (B-D) showing the gene cluster of $c y r$ which encodes cylindrospermopsin from various syanobacterial species namely; (B) C. raciborskii AWT205; (C) Aphanizomenon sp. strain 10E6 and (D) $R$. curvata CHAB1150, respectively; red bars indicates the transposase coding region or vestiges thereof [96].

A

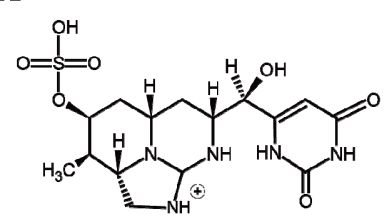

Cylindrospermopsin

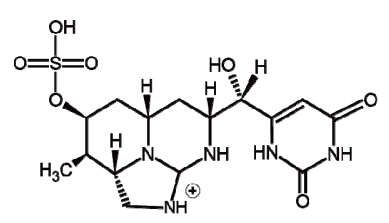

7-epicylindrospermopsin

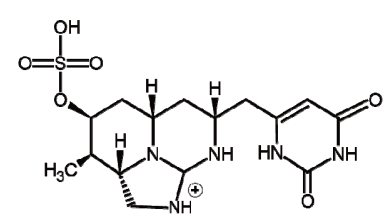

7-deoxycylindrospermopsin

B

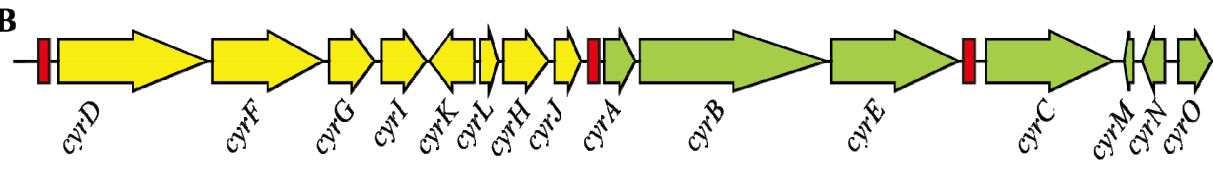

C

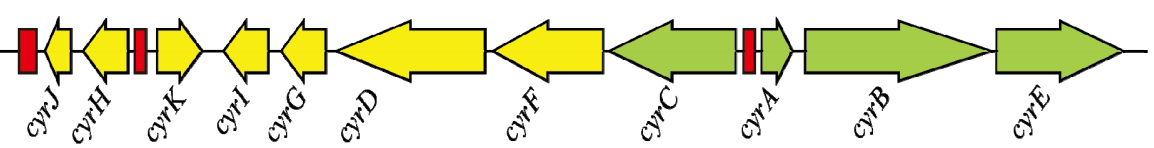

D

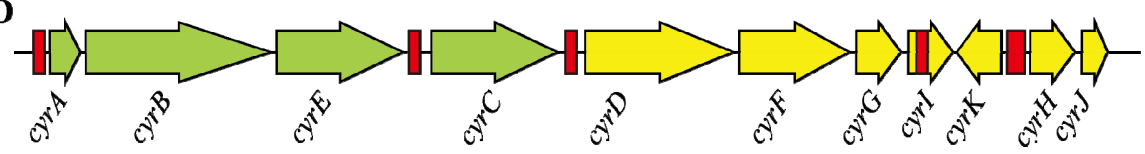


CYN has hepatotoxic, nephrotoxic and general cytotoxic properties and it also acts as a potential carcinogen [97-99]. CYN primarily inhibit protein, cytochrome $\mathrm{P} 450$ and glutathione synthesis which may lead to cell death [97-101]. CYN have affected mainly the liver, kidney, lung and intestine in the mouse bioassays [102]. When compared to MCs, CYN causes cell death through irreversible inhibition of protein synthesis [99]. The other effects of CYN are micronucleus induction, chromosome loss, tumor initiation and fetal toxicity $[98,103,104]$. However, various human and animal intoxications have been reported including famous Palm Island mystery disease [14,15,105,106]. In the Palm Island of Australia, during 1979, 139 children and 10 adults suffering from hepato-enteritis were admitted to the hospital after the consumption of drinking water treated with algicide to eliminate cyanobacteria; this outbreak was caused by the release of CYN [106].

\subsection{Transcription of Cylindrospermopsin Synthetase Gene}

The cylindrospermopsin biosynthesis has been carried out by the cyr gene cluster which was studied in several cyanobacteria including C. raciborskii strains, Aphanizmoenon sp. 10E6 and Oscillatoria sp. PCC 6506 (Figure 2B) [81,107,108]. The size of the cyr cluster spans around $42 \mathrm{~kb}$ which contains 15ORFs ( $c y r A-O$ ) which encode all the necessary functions for biosynthesis, regulation and export of CYN [108]. A recent study comparing genomes of both toxic and non-toxic strains revealed that the cyr cluster is completely absent in non-CYN producing strains; however, mutations and alterations in cyr cluster did not affect the toxin synthesis [85]. This cluster is highly conserved among various CYN producing cyanobacterial genera. However, the gene arrangements in the cluster vary between different genera [12]. The cyrO of cyr cluster has been absent in Oscillatoria PCC 6506; however, it contains sequences for two additional transposases and an ATP-grasp type protein which has no apparent role in $\mathrm{CYN}$ biosynthesis [81]. It also suggested that the horizontal gene transfer of cyr cluster is possible because of the following properties, including possession of high GC contents, difference in flanking genes, highly conserved sequences across genera and the presence of transposases [107]. CYN biosynthesis involved many complex enzymes including NRPS/PKS-type enzymes, amidino transferase and other tailoring enzymes [109]. Even though CYN biosynthesis gene cluster has been characterized in several cyanobacteria, only a handful of reports are available on studies focusing on its promoter structure and transcriptional organization. Further, within this $c y r$ cluster, sequence motifs for the binding of global nitrogen regulator NtcA were also found. In C. raciborskii AWT205, both sides of the cyr cluster are flanked by hyp genes, which are regulated by $\mathrm{NtcA}$ and involved in maturation of hydrogenases [14,67]. It appears that cyr cluster could have been inserted in to the hyp genes, as these hyp genes generally present as clusters in cyanobacteria. Further, the presence of transposase-like sequences within the cyr cluster supports this view [14]. It was also suggested that the regulation of $c y r$ cluster by NtcA was a consequence of insertion of whole $c y r$ cluster in to hyp genes [108]; however, this view is yet to be supported by experimental evidences. Two transcription start sites each for the genes aoaA (homologue of $c y r A$ ) and aoaC (homologue of $c y r C$ ) were found in Aph. ovalisporum and their functions under different growth conditions such as nitrogen availability and light intensity were studied. However, from these results it was suggested that the transcription of aoa genes may be regulated by two promoters; one constitutive promoter and another for differential regulation under different environmental conditions [110]. It is also found that the 
synthesis of CYN and deoxy-CYN were a constitutive process and both the concentration and ratio between the release of $\mathrm{CYN}$ and deoxy-CYN varied among different strains of $C$. raciborskii [111]. In addition, proposed transcript initiation sites of $a o a A$ and $a o a C$ genes were specifically bound by a protein-like transcriptional regulator $\mathrm{AbrB}$, which suggests the involvement of such protein in the regulation of CYN production and the genomes of Oscillatoria sp. PCC6506 and C. raciborskii CS-505 showed the sequences for AbrB-like proteins [81]. Regulator binding sites with similar conserved sequences were reported in the upstream region of $a$ oaClcyrC genes and this study also supported that the mechanism of transcriptional regulation might be same in these two organisms.

\subsection{Role of Environmental Factors in CYN Production}

Production of CYN was being influenced by nutrients and majorly by light. $\mathrm{N}$ source $\left(\mathrm{NO}_{3}{ }^{-} \mathrm{NH}_{4}{ }^{+}, \mathrm{N}_{2}\right)$ has a major impact on CYN synthesis and discrepancies were also reported regarding CYN production and N-source since the studies were done with different growth conditions. An investigation about CYN and $\mathrm{N}$ source was started by Saker and Neilan [112] in C. raciborskii. In study by Shalev-Malul et al. [110], up regulation of aoaA ( 2.5-fold) and aoaC (4-fold) was reported while there was no change in the remaining CYN concentration and there no significant changes (except slight down regulation under ammonia) were observed in the transcription of cyr genes (cyrB, cyrI, cyrJ and cyrK) under various $\mathrm{N}$ sources in C. raciborskii CS-505 [113]. When the cultures of C. raciborskii cells were grown with lack of a fixed-nitrogen source, CYN was increased more while the growth rate was low; $\mathrm{CYN}$ was less with $\mathrm{NH}_{4}{ }^{+}$source while the growth rate was high; more over significant changes were not observed with $\mathrm{NO}_{3}{ }^{-}$source [112]. Phosphate limitation also plays an important role in $\mathrm{CYN}$ production but contradictions were reported regarding phosphate limitation and CYN production. Bacsi et al. [114] indicated the decrease in CYN under phosphate limitation and the increased expression of alkaline phosphatase secretion in Aph. ovalisporum. However, in study [115], an increase in CYN production was observed with phosphate limitation in Aph. ovalisporum. The authors also found induced level of alkaline phosphatase secretion and Pi-uptake transporters when they used spent Aph. ovalisporum medium and this was not the case with purified CYN alone. However, a phosphate addition both alone and with $\mathrm{NO}_{3}$ has increased the CYN concentrations in mesocosm experiments dominated by C. raciborskii [116]. Further, the proportion between cyrA and $16 S$ genes in the $C$. raciborskii population was also found to be higher in $\mathrm{P}$ addition treatments with higher intracellular CYN concentrations, which suggests that phosphate addition may favor toxic strains than non-toxic strains [116]. However, a shift between toxic and non-toxic strain dominance has already been reported. Changes in biovolume of $C$. raciborskii were lower than changes in intracellular toxin concentration suggesting a shift in the proportion of toxic and non-toxic cells. The importance of shifts in strain dominance of $C$. raciborskii has previously been proposed after comparing intracellular CYNs, the $c y r C$ toxin gene and the rpoC1 gene of $C$. raciborskii in a bloom population [117]. In addition, intracellular $\mathrm{CYN}$ concentrations were found to be higher at increased $\mathrm{P}$ concentration in a Saudi lake [118]. However, the molecular mechanisms lying behind the alteration in strain differences in $C$. raciborskii to the addition of $\mathrm{P}$ addition are unclear and necessitate more research. Regarding the light intensity, high light intensity $\left(85 \mu \mathrm{mol}\right.$ photons $\left.\mathrm{m}^{-2} \cdot \mathrm{s}^{-1}\right)$ was found to affect $c y r$ transcription initially (after $8 \mathrm{~h}$ ) and increased the same after given time (24 and $48 \mathrm{~h}$ ) in 
Aph. ovalisporum [110]. The combination of high light intensity $\left(140 \mu \mathrm{mol}\right.$ photons $\left.\mathrm{m}^{-2} \cdot \mathrm{s}^{-1}\right)$ and medium lack of nitrogen increased the production of CYN while the lower growth rate was indicated under high light intensity [119]. Intracellular and extracellular measurement of CYN in Oscillatoria sp. PCC 6506 under different light conditions showed that total CYN content is highest during the exponential growth phase at intermediate light level $\left(10 \mu \mathrm{mol}\right.$ photons $\left.\mathrm{m}^{-2} \cdot \mathrm{s}^{-1}\right)$ and also during the stationary growth phase at extreme lower and higher light levels with the extracellular form ranged between $56 \%$ and $96 \%$ of the total CYN concentrations [120]. CYN synthesis was reported to be less with sulfate exposure in Aph. ovalisporum [114]. Further, cyrJ was up-regulated by the addition of an allelopathic compound pyrogallic acid at the concentration of $4 \mathrm{mg} \cdot \mathrm{L}^{-1}$ in C. raciborskii [121]. These studies clearly indicate that various environmental factors influence CYN production by various cyanobacteria. However, indepth analysis in the future is required to understand how these environmental variables alter CYN production and strain composition.

\section{Anatoxins (ATXs)}

\subsection{Structure and Occurrence of ATXS}

Anatoxins are alkaloids produced by various cyanobacteria including, Anabaena, Oscillatoria and Aphanizomenon [122,123]. To date, three common anatoxins have been identified from cyanobacteria namely anatoxin-a (ATX-a), homoanatoxin-a (hATX-a) and anatoxin-a(s) (ATX-a(s)). Although ATX-a (165 Da) and hATX-a are secondary amines, hATX-a varies from ATX-a by its methylation at the ketone structure; ATX-a(s) (252 Da) has different structure which is a phosphate ester of a cyclic $N$-hydroxyguanidine (Figure 3A) [24,123]. ATX-a is soluble in water and not stable under alkaline condition and sunlight; ATX-a was also not stable under high UV-B radiation and high temperature; stability of ATX-a(s) was also changed with alkaline condition and heat [124-126]. These neurotoxins all inhibit the activity of acetylcholinesterase and affect muscle function by causing constriction, convulsion and respiratory dysfunction, which eventually leads to death [127]. Different animal poisonings were reported with ATX-a and its variants [128-130]; hypersalivation was reported with ATX-a(s) [131]. Although no guidelines were reported with ATX toxicity in water, the animal experiments showed LD50 for ATX-a is $375 \mu \mathrm{g} / \mathrm{kg}$ (via i.p. route in mice) and $>5000 \mu \mathrm{g} / \mathrm{kg}$ via oral [132]. ATX-a(s) was more effective than ATX-a; LD50 of ATX-a(s) is $20 \mu \mathrm{g} / \mathrm{kg}$ [127]. The study [133] has given the detection protocol for ATX-a and its three analogues based on fluorescent polarization (FP) method.

ATX-a(s) has been produced only by Anabaena sp. while ATX-a has been produced by various genera of cyanobacteria including Anabaena, Aphanizomenon, Planktothrix, Microcystis, Oscillatoria and Cylindrospermum. ATX-a has been reported widely including in America, Asia, Africa and in Europe; however, the presence of ATX-a(s) was observed only from a few regions of the United States, Scotland, Denmark and Brazil [132].

\subsection{Transcription of Ana Cluster}

ATX-a and its variants were synthesized by the addition of prolin by NRPS (non-ribosomal peptide synthetases) and subsequent chain extension and cyclization was done by PKS (polyketide synthases) [122]. ATX gene cluster anaA-anaG and ORF1 was described by [134] (Figure 3B). It was 
reported from Oscillatoria sp. PCC6506 [135] and Anabaena sp. 37 [134] with high sequence similarity and different organization in these spp. The study [134] described the ana gene cluster in Anabaena sp. 37; ana cluster contains four or five operons with characteristic sequence motifs in the upstream without any RNA Polymerase binding site. They also indicated that two clusters of ana gene $(29 \mathrm{~kb})$ have been described in the opposite direction with $6 \mathrm{~kb}$ spacer region. Molecular methods have been developed to detect anatoxins [134]. To date, studies on the regulation of ana cluster is in its infancy and further studies are needed.

Figure 3. (A) Shows the variants of Anatoxins; The ana cluster encodes anatoxin from (B) Anabaena sp. strain 37 and (C) Oscillatoria sp. PCC6506 (adapted from [134]).

A<smiles>CC(=O)C1=CCC[C@H]2CC[C@H]1N2</smiles>

Anatoxin-a

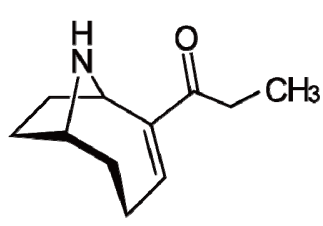

Homoanatoxin-a<smiles>COP1(=O)NP2(=O)O[NH+]=C(CN(C)C)N(O1)O2</smiles>

Anatoxin-a(s)

B

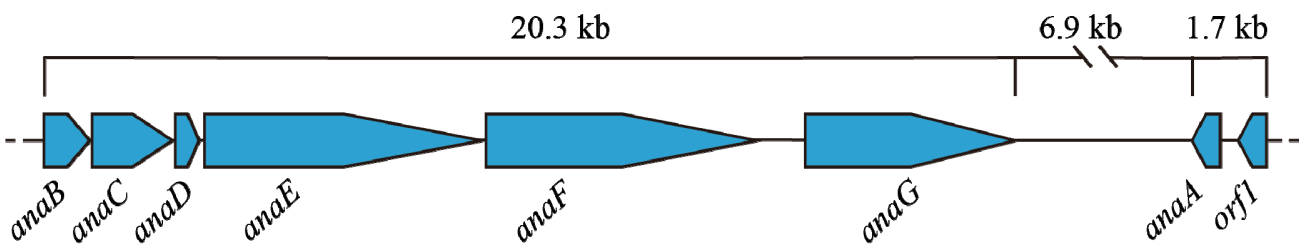

C

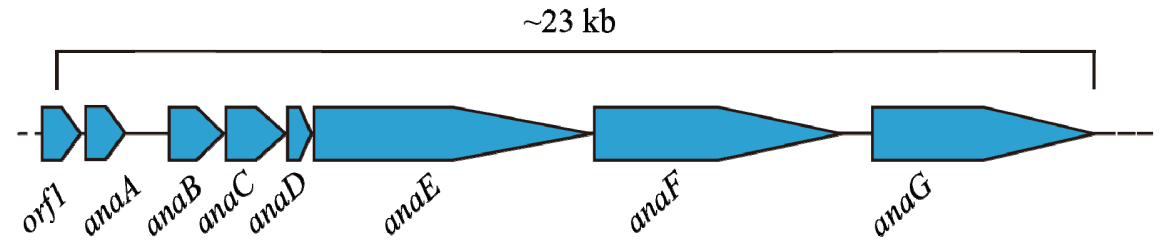

\subsection{Environmental Impact on ATX}

Variation in synthesis of ATXs was reported with nutrient limitation, light, temperature and different growth phase [65,136-139]. These toxins were not related to cell growth, while MC is associated with growth rate as mentioned by [53]. N starvation could increase ATX production as we already mentioned above for other cyanobacterial toxins [14]. Reduction of ATX-a synthesis was reported in Anabaena and Aphanizomenon strains with high temperatures despite of their growth rate [138]. Studies [138,140] revealed that sub optimal level of light and temperatures were helped to produce more ATXs and also lower light was associated with extracellular ATX production in Anabaena. The work in [141] suggested the role of temperature and media composition in ATX production; synthesis of ATX-a was observed in Ocillatoria sp. PCC6506 in BG11 media at $22{ }^{\circ} \mathrm{C}$ without $\mathrm{CO}_{2}$ enrichment while the synthesis of hATX-a was observed in BG1110 media supplemented with $10 \mathrm{mM} \mathrm{NaHCO}_{3}$ at $25{ }^{\circ} \mathrm{C}$ with $\mathrm{CO}_{2}$ enrichment in the same. Addition of green algal extract (Chlamydomonas reinhardtii) enhanced the toxin level in A. flos-aquae batch cultures as reported by [142]. 


\section{Saxitoxin}

\subsection{Structure and Toxicity of STXS}

Saxitoxin (STXs) comes under the class of alkaloids which share tricyclic backbone with different side group moieties. Fifty seven analogues of saxitoxin have been reported [143]; they have been also known as paralytic shellfish toxins (Figure 4A). Toxicity of analogues of saxitoxin mainly depends upon the interactions between guanidinium ions and the target molecules [144]. These neuro toxins are known to inhibit the function of voltage-gated channels in vertebrates [145,146]. These toxins have been produced by various cyanobacterial genera including Anabaena, Aphanizomenon, Cylindrospermopsis, Lyngbya, Planktothrix, Raphidiopsis, Scytonema and dinoflagellates [14].

STXs come under a family of tricyclic compounds (241 to $491 \mathrm{Da}$ ); about 20 variants of STXs were reported including singly sulphated or doubly sulphated, non-sulphated and decarbamoyl derivative STXs [132,147]. Their stability in water is about 90 days [148] and further degrading into high toxic variants under high temperature determined their toxicity. These neurotoxins are the main cause for the paralytic shellfish poisonings and they showed LD50 of $10 \mu \mathrm{g} / \mathrm{kg}$ (in mice) as reported by [23]. They were found to inhibit the sodium ion channels and affect nerve function; which causes severe paralyses with respiratory failure and finally leads to death [24]. Mortality events (109 cases) by paralytic shellfish poisonings have been reported in North and Central America [23], although no reports are available about human intoxication through the water. Although the chlorination was found to reduce the acute toxicity most of the cyanotoxins, including MC, CYN, NOD, and STX, the actual reaction and toxic nature of by-products was only identified in $\mathrm{MC}$ and $\mathrm{CYN}$ and not identified in case of STX and NOD with chlorine [132].

\subsection{Regulation of STX Production}

To date, very few investigations have been done regarding saxitoxin regulation. Bioinformatic analyses of Kellmann et al. [149] indicated that the synthesis of STX begun with the multifunctional polyketide biosynthesis enzyme $(S x t A)$. Only a few studies are evident about STX genes; to date STX biosynthetic gene cluster has been reported from five genera of cyanobacteria [107,108,149-151] and 33 genes involved in STX biosynthesis, transport and regulation were also reported in their study. The size of these gene clusters was $25.7 \mathrm{~kb}$ (Raphidiopsis brookii D9) to $36 \mathrm{~kb}$ (Lyngbya wollei). However, the toxic profile of the each strain is determined by the position/presence or absence of genes in the above cluster (Figure 4B-D). Studies on C. raciborskii T3, revealed the presence of $\operatorname{sxt} Y$, sxtZ and $o m p R$ genes which are being involved in STX regulation. More experimentation is required to know the actual mechanism behind this, but these proteins showed homology with the phosphate stress-activated two-component signal transduction system [149]. Further understanding about STX warrants new experiments regarding its genomics and proteomics, but methodology for 2D-PAGE have been developed in C. raciborskii and Raphidiopsis sp. [152]. Recently, genetically predicted biosynthetic intermediate of STX such as Int-A, Int-C2 and D2 have been identified and quantified in Anabaena circinalis [153], which support the biosynthetic route completely as proposed by Kellmann et al. [149]. 
Figure 4. (A) Shows the structure of saxitoxin; (B-D) showing the gene cluster encodes saxitoxin from Aphanizomenon. sp. NH-5, Anabaena circinalis AWQC131C and Cylindrospermopsis raciborskii $\mathrm{T} 3$ respectively (not drawn to scale) [154].

A<smiles>NC(=O)OC[C@H]1N[C@@H]([NH3+])N2CCC(O)(O)[C@]23NC(=[NH2+])N[C@H]13</smiles>

\section{B}

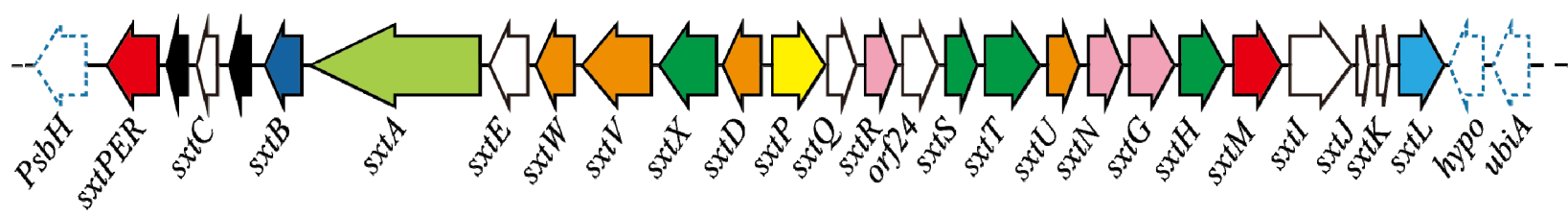

C
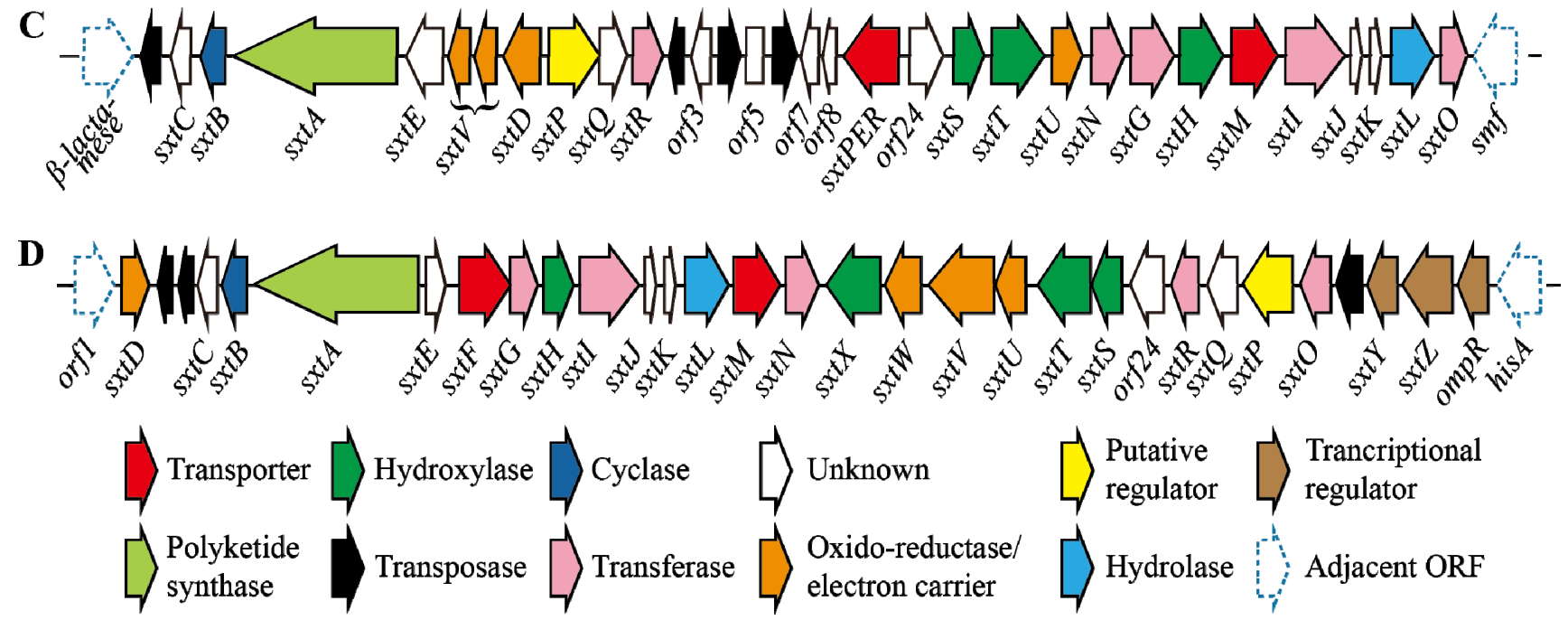

\subsection{Impact of Environmental Factors}

Synthesis of STX has been changed by the environmental factors; nutrients, light, growth temperature and salt concentrations found to have a potential impact on STX production (Table 2). The high ratio of nitrogen to phosphorous influenced the STX production in C. raciborskii; high N:P treatment has increased the STX production nearly one fold when compared to low N:P [155]. However, with increased concentrations of nitrogen, a lower level of STX has been observed in Raphidiopsis brookii [156]. Production of STX was recorded as more with high light intensity (100 $\mu$ mol photons $\mathrm{m}^{-2} \cdot \mathrm{s}^{-1}$ ) when compared with 50 and $150 \mu \mathrm{mol}$ photons $\mathrm{m}^{-2} \cdot \mathrm{s}^{-1}$ light in $C$. raciborskii T3; reduction of STX in dark was also reported in C. raciborskii T3. Moreover, these studies suggested the role of circadian clock in STX production [157,158]. Contradictory results were reported regarding the growth temperature and STX production as we mentioned in other toxins; when compared with optimal growth temperature of $25{ }^{\circ} \mathrm{C}$, STX production was being more (especially the extracellular toxin concentration) at $19{ }^{\circ} \mathrm{C}$, although the growth rate was less in C. raciborskii strain C10 [159]. However, a high temperature $\left(28{ }^{\circ} \mathrm{C}\right)$ seems to induce the STX production in 
Aphanizomenon sp. LMECYA 31 more than the usual growth temperature $22{ }^{\circ} \mathrm{C}$ [160]. Work of Pomati et al. [161] revealed that extracellular $\mathrm{NaCl}$ has increased the production of STX and this was also confirmed by the presence of saxitoxin-producing cyanobacteria C. raciborskii $\mathrm{T} 3$ in waters with high conductivity; their study also suggested that this STX production might have impact on sodium channels in the cells [161]. STXs necessitate more research since we have only a poor understanding about STX gene regulation and pathways to date.

Table 2. Effect of various factors on the regulation of various cyanotoxins (see text for further details).

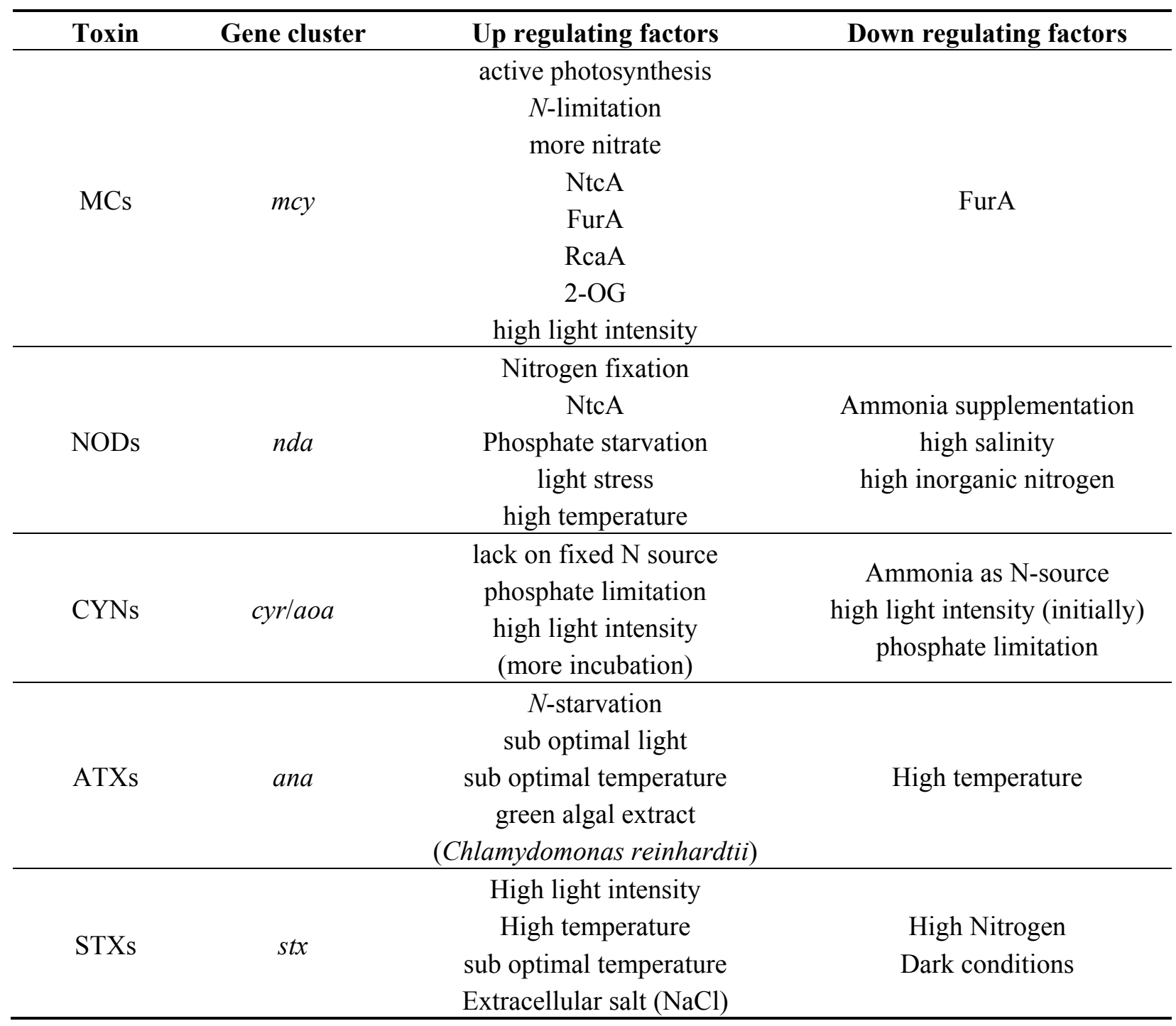

\section{Conclusions and Future Remarks}

Recently, expanding cyanobacterial blooms has been a major target of researchers because of their harmful toxin production. These toxins are regulated by so many factors including nutrients' limitations (Nitrogen, phosphorous and Carbon), light, heat, oxidants and other components. Studies regarding cyanobacterial toxins and the role of environmental factors in these toxins should be compiled to understand clearly about the effect of toxins in the environment. As we stated above, the ability of toxin producers to adapt to all environmental conditions was very high when compared with non-toxin producers; these toxins were also found to play a vital role in their growth rate. In this 
review we have compiled the essential information regarding the synthesis and regulation of cyanobacterial toxins to date (see Table 2). We stress in this review that stressors are found to have an important role in the regulation of these toxins. Although the cyanobacterial research started a few decades ago, studies regarding the gene regulation and the impact of environmental factors in toxin production are still in their infancy because of the complexity in the system. Moreover, studies describing about toxin synthesis and regulation were not done under similar conditions and thus could not be compared to many of these studies. Although the laboratory experiments provide essential information regarding toxins, more field experiments are needed to know the role of environmental factors in them, although this is usually associated with many practical concerns. In the future, further molecular studies are needed to provide a clear view about the factors influencing toxin production.

\section{Acknowledgments}

We thank the anonymous reviewers for their valuable comments, which helped us to improve the quality of this review. This work was supported by the National Research Foundation of Korea Grant funded by the Korean Government (NRF-M1A5A1-2013-044476, and 2013R1A1A2013596), and by the "Eco-innovation project" of the Ministry of Environment, Korea, funded to Jang-Seu Ki.

\section{Author Contributions}

Thangavelu Boopathi has conceived the idea, conducted research on the topics and written this review. Jang-Seu Ki contributed in idea development and funding support in addition to the overall editing and revising the manuscript.

\section{Conflicts of Interest}

The authors declare no conflict of interest.

\section{References}

1. Paerl, H.W.; Paul, V.J. Climate change: Links to global expansion of harmful cyanobacteria. Water Res. 2012, 46, 1349-1363.

2. Knoll, A.H. Cyanobacteria and Earth History. In The Cyanobacteria: Molecular Biology, Genomics, and Evolution; Herrero, A., Flores, E., Eds.; Caister Academic Press: Norfolk, UK, 2008; p. 484.

3. Schopf, J.W. The Fossil Record: Tracing the Roots of the Cyanobacterial Lineage. In The Ecology of Cyanobacteria; Whitton, B., Potts, M., Eds.; Kluwer Academic Publishers: Dordrecht, The Netherlands, 2002; pp. 13-35.

4. Paerl, H.W.; Otten, T.G. Harmful cyanobacterial blooms: Causes, consequences, and controls. Microb. Ecol. 2013, 65, 995-1010.

5. Steffen, M.M.; Li, Z.; Effler, T.C.; Hauser, L.J.; Boyer, G.L.; Wilhelm, S.W. Comparative metagenomics of toxic freshwater Cyanobacteria bloom communities on two continents. PLoS One 2012, 7, e44002. 
6. Suikkanen, S.; Pulina, S.; Engstrom-Ost, J.; Lehtiniemi, M.; Lehtinen, S.; Brutemark, A. Climate change and eutrophication induced shifts in northern summer plankton communities. PLoS One 2013, 8, e66475.

7. Paerl, H.W.; Huisman, J. Blooms like it hot. Science 2008, 320, 57-58.

8. Elliott, J.A. Is the future blue-green? A review of the current model predictions of how climate change could affect pelagic freshwater cyanobacteria. Water Res. 2012, 46, 1364-1371.

9. Corbel, S.; Mougin, C.; Bouaicha, N. Cyanobacterial toxins: Modes of actions, fate in aquatic and soil ecosystems, phytotoxicity and bioaccumulation in agricultural crops. Chemosphere 2014, 96, 1-15.

10. O’Neil, J.M.; Davis, T.W.; Burford, M.A.; Gobler, C.J. The rise of harmful cyanobacteria blooms: The potential roles of eutrophication and climate change. Harmful Algae 2012, 14, 313-334.

11. Cheung, M.Y.; Liang, S.; Lee, J. Toxin-producing cyanobacteria in freshwater: A review of the problems, impact on drinking water safety, and efforts for protecting public health. J. Microbiol. 2013, 51, 1-10.

12. Kaplan, A.; Harel, M.; Kaplan-Levy, R.N.; Hadas, O.; Sukenik, A.; Dittmann, E. The languages spoken in the water body (or the biological role of cyanobacterial toxins). Front. Microbiol. 2012, 3, 138:1-138:11.

13. Kaebernick, M.; Neilan, B.A. Ecological and molecular investigations of cyanotoxin production. FEMS Microbiol. Ecol. 2001, 35, 1-9.

14. Neilan, B.A.; Pearson, L.A.; Muenchhoff, J.; Moffitt, M.C.; Dittmann, E. Environmental conditions that influence toxin biosynthesis in cyanobacteria. Environ. Microbiol. 2013, 15, 1239-1253.

15. Pearson, L.; Mihali, T.; Moffitt, M.; Kellmann, R.; Neilan, B. On the chemistry, toxicology and genetics of the cyanobacterial toxins, microcystin, nodularin, saxitoxin and cylindrospermopsin. Mar. Drugs 2010, 8, 1650-1680.

16. Leão, P.N.; Vasconcelos, M.T.; Vasconcelos, V.M. Allelopathy in freshwater cyanobacteria. Crit. Rev. Microbiol. 2009, 35, 271-282.

17. Leão, P.N.; Vasconcelos, M.T.S.; Vasconcelos, V.M. Allelopathic activity of cyanobacteria on green microalgae at low cell densities. Eur. J. Phycol. 2009, 44, 347-355.

18. Kleinteich, J.; Wood, S.A.; Kupper, F.C.; Camacho, A.; Quesada, A.; Frickey, T.; Dietrich, D.R. Temperature-related changes in polar cyanobacterial mat diversity and toxin production. Nat. Clim. Chang. 2012, 2, 356-360.

19. Eiler, A.; Drakare, S.; Bertilsson, S.; Pernthaler, J.; Peura, S.; Rofner, C.; Simek, K.; Yang, Y.; Znachor, P.; Lindstrâm, E.S. Unveiling distribution patterns of freshwater phytoplankton by a next generation sequencing based approach. PLoS One 2013, 8, e53516.

20. Park, S.; Brett, M.T.; Muller-Solger, A.; Goldman, C.R. Climatic forcing and primary productivity in a subalpine lake: Interannual variability as a natural experiment. Limnol. Oceanogr. 2004, 49, 614-619.

21. Kosten, S.; Huszar, V.L.M.; Bécares, E.; Costa, L.S.; van Donk, E.; Hansson, L.-A.; Jeppesen, E.; Kruk, C.; Lacerot, G.; Mazzeo, N.; et al. Warmer climates boost cyanobacterial dominance in shallow lakes. Glob. Chang. Biol. 2012, 18, 118-126. 
22. Wilhelm, S.W.; Farnsley, S.E.; LeCleir, G.R.; Layton, A.C.; Satchwell, M.F.; DeBruyn, J.M.; Boyer, G.L.; Zhu, G.; Paerl, H.W. The relationships between nutrients, cyanobacterial toxins and the microbial community in Taihu (Lake Tai), China. Harmful Algae 2011, 10, 207-215.

23. Kuiper-Goodman, T.; Falconer, I.; Fitzgerald, J. Human Health Aspects. In Toxic Cyanobacteria in Water: A Guide to Their Public Health Consequences, Monitoring and Management; Chorus, I., Bartram, J., Eds.; E \& FN Spon Publishers: London, UK, 1999; p. 36.

24. Van Apeldoorn, M.E.; van Egmond, H.P.; Speijers, G.J.; Bakker, G.J. Toxins of cyanobacteria. Mol. Nutr. Food. Res. 2007, 51, 7-60.

25. Carmichael, W.W. Health effects of toxin-producing cyanobacteria: "The CyanoHAB". Hum. Ecol. Risk Assess. 2001, 7, 1393-1407.

26. Zilliges, Y.; Kehr, J.-C.; Meissner, S.; Ishida, K.; Mikkat, S.; Hagemann, M.; Kaplan, A.; Börner, T.; Dittmann, E. The cyanobacterial hepatotoxin microcystin binds to proteins and increases the fitness of Microcystis under oxidative stress conditions. PLoS One 2011, 6, e17615.

27. Kurmayer, R. The toxic cyanobacterium Nostoc sp. strain 152 produces highest amounts of microcystin and nostophycin under stress conditions. J. Phycol. 2011, 47, 200-207.

28. Fischer, W.J.; Dietrich, D.R. Pathological and biochemical characterization of microcystin-induced hepatopancreas and kidney damage in carp (Cyprinus carpio). Toxicol. Appl. Pharmacol. 2000, 164, 73-81.

29. Fischer, W.J.; Altheimer, S.; Cattori, V.; Meier, P.J.; Dietrich, D.R.; Hagenbuch, B. Organic anion transporting polypeptides expressed in liver and brain mediate uptake of microcystin. Toxicol. Appl. Pharmacol. 2005, 203, 257-263.

30. Jochimsen, E.M.; Carmichael, W.W.; An, J.; Cardo, D.M.; Cookson, S.T.; Holmes, C.E.; Antunes, M.B.; Filho, D.A.D.; Lyra, T.M.; Barreto, V.S.T. Liver failure and death after exposure to microcystins at a hemodialysis center in Brazil. N. Engl. J. Med. 1998, 338, 873-878.

31. Zeng, C.; Sun, H.; Xie, P.; Wang, J.; Zhang, G.; Chen, N.; Yan, W.; Li, G. The role of apoptosis in MCLR-induced developmental toxicity in zebrafish embryos. Aquat. Toxicol. 2014, 149, 25-32.

32. Niedermeyer, T.J.; Schmieder, P.; Kurmayer, R. Isolation of Microcystins from the Cyanobacterium Planktothrix rubescens Strain No80. Nat. Prod. Bioprospect. 2014, 4, 37-45.

33. Rastogi, R.P.; Sinha, R.P.; Incharoensakdi, A. The cyanotoxin-microcystins: Current overview. Rev. Environ. Sci. Biotechnol. 2014, 13, 215-249.

34. Gehringer, M.M.; Wannicke, N. Climate change and regulation of hepatotoxin production in Cyanobacteria. FEMS Microbiol. Ecol. 2014, 88, 1-25.

35. Neilan, B.A.; Pearson, L.A.; Moffitt, M.C.; Mihali, K.T.; Kaebernick, M.; Kellmann, R.; Pomati, F. The genetics and genomics of cyanobacterial toxicity. In Cyanobacterial Harmful Algal Blooms: State of the Science and Research Needs; Hudnell, H.K., Ed.; Springer: New York, NY, USA, 2008; pp. 417-452.

36. Kaasalainen, U.; Fewer, D.P.; Jokela, J.; Wahlsten, M.; Sivonen, K.; Rikkinen, J. Cyanobacteria produce a high variety of hepatotoxic peptides in lichen symbiosis. Proc. Natl. Acad. Sci. USA 2012, 109, 5886-5891.

37. Kaasalainen, U.; Fewer, D.P.; Jokela, J.; Wahlsten, M.; Sivonen, K.; Rikkinen, J. Lichen species identity and diversity of cyanobacterial toxins in symbiosis. New Phytol. 2013, 198, 647-651. 
38. Moffitt, M.C.; Neilan, B.A. Characterization of the nodularin synthetase gene cluster and proposed theory of the evolution of cyanobacterial hepatotoxins. Appl. Environ. Microbiol. 2004, $70,6353-6362$.

39. Alexova, R.; Haynes, P.; Ferrari, B.; Neilan, B. Comparative protein expression in different strains of the bloom-forming cyanobacterium Microcystis aeruginosa. Mol. Cell. Proteomics 2011, 10, 3749-3765.

40. Wood, S.A.; Kuhajek, J.M.; Winton, M.; Phillips, N.R. Species composition and cyanotoxin production in periphyton mats from three lakes of varying trophic status. FEMS Microbiol. Ecol. 2012, 79, 312-326.

41. Rouhiainen, L.; Vakkilainen, T.; Siemer, B.L.; Buikema, W.; Haselkorn, R.; Sivonen, K. Genes coding for hepatotoxic heptapeptides (microcystins) in the cyanobacterium Anabaena strain 90. Appl. Environ. Microbiol. 2004, 70, 686-692.

42. Christiansen, G.; Fastner, J.; Erhard, M.; Börner, T.; Dittmann, E. Microcystin biosynthesis in Planktothrix: Genes, evolution, and manipulation. J. Bacteriol. 2003, 185, 564-572.

43. Kaebernick, M.; Dittmann, E.; Börner, T.; Neilan, B.A. Multiple alternate transcripts direct the biosynthesis of microcystin, a cyanobacterial. Appl. Environ. Microbiol. 2002, 68, 449-455.

44. Ginn, H.P.; Pearson, L.A.; Neilan, B.A. NtcA from Microcystis aeruginosa PCC 7806 is autoregulatory and binds to the microcystin promoter. Appl. Environ. Microbiol. 2010, 76, 4362-4368.

45. Alexova, R.; Fujii, M.; Birch, D.; Cheng, J.; Waite, T.D.; Ferrari, B.C.; Neilan, B.A. Iron uptake and toxin synthesis in the bloom-forming Microcystis aeruginosa under iron limitation. Environ. Microbiol. 2011, 13, 1064-1077.

46. Su, Z.; Olman, V.; Mao, F.; Xu, Y. Comparative genomics analysis of NtcA regulons in cyanobacteria: Regulation of nitrogen assimilation and its coupling to photosynthesis. Nucleic Acids Res. 2005, 33, 5156-5171.

47. Luque, I.; Vazquez-Bermudez, M.F.; Paz-Yepes, J.; Flores, E.; Herrero, A. In vivo activity of the nitrogen control transcription factor NtcA is subjected to metabolic regulation in Synechococcus sp. strain PCC 7942. FEMS Microbiol. Lett. 2004, 236, 47-52.

48. Ramasubramanian, T.S.; Wei, T.F.; Oldham, A.K.; Golden, J.W. Transcription of the Anabaena sp. strain PCC 7120 ntcA gene: Multiple transcripts and NtcA binding. J. Bacteriol. 1996, 178, 922-926.

49. Kuniyoshi, T.M.; Gonzalez, A.; Lopez-Gomollon, S.; Valladares, A.; Bes, M.T.; Fillat, M.F.; Peleato, M.L. 2-oxoglutarate enhances NtcA binding activity to promoter regions of the microcystin synthesis gene cluster. FEBS Lett. 2011, 585, 3921-3926.

50. Ermilova, E.V.; Forchhammer, K. PII signaling proteins of cyanobacteria and green algae. New features of conserved proteins. Russ. J. Plant Physiol. 2013, 60, 483-490.

51. Zhao, M.-X.; Jiang, Y.-L.; He, Y.-X.; Chen, Y.-F.; Teng, Y.-B.; Chen, Y.; Zhang, C.-C.; Zhou, C.-Z. Structural basis for the allosteric control of the global transcription factor NtcA by the nitrogen starvation signal 2-oxoglutarate. Proc. Natl. Acad. Sci. USA 2010, 107, 12487-12492.

52. Herrero, A.; Muro-Pastor, A.; Flores, E. Nitrogen control in cyanobacteria. J. Bacteriol. 2001, $183,411-425$.

53. Long, B.M.; Jones, G.J.; Orr, P.T. Cellular microcystin content in N-limited Microcystis aeruginosa can be predicted from growth rate. Appl. Environ. Microbiol. 2001, 67, 278-283. 
54. Utkilen, H.; Gjølme, N. Toxin production by Microcystis aeruginosa as a function of light in continuous cultures and its ecological significance. Appl. Environ. Microbiol. 1992, 58, 1321-1325.

55. Downing, T.G.; Meyer, C.; Gehringer, M.M.; van de Venter, M. Microcystin content of Microcystis aeruginosa is modulated by nitrogen uptake rate relative to specific growth rate or carbon fixation rate. Environ. Toxicol. 2005, 20, 257-262.

56. Downing, T.G.; Sember, C.S.; Gehringer, M.M.; Leukes, W. Medium N:P ratios and specific growth rate comodulate microcystin and protein content in Microcystis aeruginosa PCC7806 and M. aeruginosa UV027. Microb. Ecol. 2005, 49, 468-473.

57. Sevilla, E.; Martin-Luna, B.; Vela, L.; Bes, M.T.; Peleato, M.L.; Fillat, M. Microcystin-LR synthesis as response to nitrogen: Transcriptional analysis of the mcyD gene in Microcystis aeruginosa PCC7806. Ecotoxicology 2010, 19, 1167-1173.

58. Tonk, L.; van de Waal, D.B.; Slot, P.; Huisman, J.; Matthijs, H.C.; Visser, P.M. Amino acid availability determines the ratio of microcystin variants in the cyanobacterium Planktothrix agardhii. FEMS Microbiol. Ecol. 2008, 65, 383-390.

59. Van de Waal, D.B.; Verspagen, J.M.H.; Lürling, M.; van Donk, E.; Visser, P.M.; Huisman, J. The ecological stoichiometry of toxins produced by harmful cyanobacteria: An experimental test of the carbon-nutrient balance hypothesis. Ecol. Lett. 2009, 12, 1326-1335.

60. Van de Waal, D.B.; Verspagen, J.M.H.; Finke, J.F.; Vournazou, V.; Immers, A.K.; Kardinaal, W.E.A.; Tonk, L.; Becker, S.; van Donk, E.; Visser, P.M.; et al. Reversal in competitive dominance of a toxic versus non-toxic cyanobacterium in response to rising $\mathrm{CO}_{2}$. ISME J. 2011, 5, 1438-1450.

61. Jahnichen, S.; Long, B.M.; Petzoldt, T. Microcystin production by Microcystis aeruginosa: Direct regulation by multiple environmental factors. Harmful Algae 2011, 12, 95-104.

62. Horst, G.P.; Sarnelle, O.; White, J.D.; Hamilton, S.K.; Kaul, R.B.; Bressie, J.D. Nitrogen availability increases the toxin quota of a harmful cyanobacterium, Microcystis aeruginosa. Water Res. 2014, 54, 188-198.

63. Monchamp, M.-E.; Pick, F.R.; Beisner, B.E.; Maranger, R. Nitrogen forms influence microcystin concentration and composition via changes in cyanobacterial community structure. PLoS One 2014, 9, e85573.

64. Ding, Y.; Song, L.; Sedmak, B. UVB Radiation as a potential selective factor favoring microcystin producing bloom forming cyanobacteria. PLoS One 2013, 8, e73919.

65. Kaebernick, M.; Neilan, B.A.; Börner, T.; Dittmann, E. Light and the transcriptional response of the microcystin biosynthesis gene cluster. Appl. Environ. Microbiol. 2000, 66, 3387-3392.

66. Tonk, L.; Visser, P.M.; Christiansen, G.; Dittmann, E.; Snelder, E.O.; Wiedner, C.; Mur, L.R.; Huisman, J. The microcystin composition of the cyanobacterium Planktothrix agardhii changes toward a more toxic variant with increasing light intensity. Appl. Environ. Microbiol. 2005, 71, 5177-5181.

67. Hansel, A.; Axelsson, R.; Lindberg, P.; Troshina, O.Y.; Wünschiers, R.; Lindblad, P. Cloning and characterisation of a hyp gene cluster in the filamentous cyanobacterium Nostoc sp. strain PCC 73102. FEMS Microbiol. Lett. 2001, 201, 59-64. 
68. Sevilla, E.; Martin-Luna, B.; Bes, M.T.; Fillat, M.; Peleato, M.L. An active photosynthetic electron transfer chain required for mcyD transcription and microcystin synthesis in Microcystis aeruginosa PCC7806. Ecotoxicology 2012, 21, 811-819.

69. Phelan, R.R.; Downing, T.G. A growth advantage for microcystin production by Microcystis PCC7806 under high light. J. Phycol. 2011, 47, 1241-1246.

70. Deblois, C.P.; Juneau, P. Relationship between photosynthetic processes and microcystin in Microcystis aeruginosa grown under different photon irradiances. Harmful Algae 2010, 9, 18-24.

71. Sevilla, E.; Martin-Luna, B.; Vela, L.; Bes, M.T.; Fillat, M.F.; Peleato, M.L. Iron availability affects $m c y D$ expression and microcystin-LR synthesis in Microcystis aeruginosa PCC7806. Environ. Microbiol. 2008, 10, 2476-2483.

72. Gehringer, M.M.; Adler, L.; Roberts, A.A.; Moffitt, M.C.; Mihali, T.K.; Mills, T.J.T.; Fieker, C.; Neilan, B.A. Nodularin, a cyanobacterial toxin, is synthesized in planta by symbiotic Nostoc sp. ISME J. 2012, 6, 1834-1847.

73. Mazur-Marzec, H.; Meriluoto, J.; Plinski, M.; Szafranek, J. Characterization of nodularin variants in Nodularia spumigena from the Baltic Sea using liquid chromatography/mass spectrometry/mass spectrometry. Rapid Commun. Mass Spectrom. 2006, 20, 2023-2032.

74. Camargo, S.; Valladares, A.; Flores, E.; Herrero, A. Transcription activation by NtcA in the absence of consensus NtcA-binding sites in an anabaena heterocyst differentiation gene promoter. J. Bacteriol. 2012, 194, 2939-2948.

75. Jonasson, S.; Vintila, S.; Sivonen, K.; El-Shehawy, R. Expression of the nodularin synthetase genes in the Baltic Sea bloom-former cyanobacterium Nodularia spumigena strain AV1. FEMS Microbiol. Ecol. 2008, 65, 31-39.

76. Vintila, S.; El-Shehawy, R. Ammonium ions inhibit nitrogen fixation but do not affect heterocyst frequency in the bloom-forming cyanobacterium Nodularia spumigena strain AV1. Microbiology 2007, 153, 3704-3712.

77. Meissner, S.; Fastner, J.; Dittmann, E. Microcystin production revisited: Conjugate formation makes a major contribution. Environ. Microbiol. 2013, 15, 1810-1820.

78. Vob, B.; Bolhuis, H.; Fewer, D.P.; Kopf, M.; Moke, F.; Haas, F.; El-Shehawy, R.; Hayes, P.; Bergman, B.; Sivonen, K.; et al. Insights into the physiology and ecology of the brackish-water-adapted cyanobacterium Nodularia spumigena CCY9414 based on a genome-transcriptome analysis. PLoS One 2013, 8, e60224.

79. Lehtimaki, J.; Moisander, P.; Sivonen, K.; Kononen, K. Growth, nitrogen fixation, and nodularin production by two baltic sea cyanobacteria. Appl. Environ. Microbiol. 1997, 63, 1647-1656.

80. Schembri, M.; Neilan, B.; Saint, C. Identification of genes implicated in toxin production in the cyanobacterium Cylindrospermopsis raciborskii. Environ. Toxicol. 2001, 16, 413-421.

81. Mazmouz, R.; Chapuis-Hugon, F.; Mann, S.; Pichon, V.; Mejean, A.; Ploux, O. Biosynthesis of cylindrospermopsin and 7-epicylindrospermopsin in Oscillatoria sp. strain PCC 6506: Identification of the cyr gene cluster and toxin analysis. Appl. Environ. Microbiol. 2010, 76, 4943-4949.

82. Harada, K.I.; Ohtani, I.; Iwamoto, K.; Suzuki, M.; Watanabe, M.F.; Watanabe, M.; Terao, K. Isolation of cylindrospermopsin from a cyanobacterium Umezakia natans and its screening method. Toxicon 1994, 32, 73-84. 
83. Banker, R.; Carmeli, S.; Hadas, O.; Teltsch, B.; Porat, R.; Sukenik, A. Identification of cylindrospermopsin in Aphanizomenon ovalisporum (Cyanophyceae) isolated from lake Kinneret, Israel. J. Phycol. 1997, 33, 613-616.

84. Bittencourt-Oliveira, M.D.C.; Piccin-Santos, V.; Kujbida, P.; Moura, A.D.N. Cylindrospermopsin in Water Supply Reservoirs in Brazil Determined by Immunochemical and Molecular Methods. J. Water Resour. Prot. 2011, 3, 349-355.

85. Sinha, R.; Pearson, L.; Davis, T.; Muenchhoff, J.; Pratama, R.; Jex, A.; Burford, M.; Neilan, B. Comparative genomics of Cylindrospermopsis raciborskii strains with differential toxicities. BMC Genomics 2014, 15, doi:10.1186/1471-2164-15-83.

86. Ohtani, C.; Ikuko, M.; Runnegar, M. Cylindrospermopsin: A potent hepatotoxin from the blue-green alga Cylindrospermopsis raciborskii. J. Am. Chem. Soc. 1992, 114, 7941-7942.

87. Spoof, L.; Berg, K.; Rapala, J.; Lahti, K.; Lepist, L.; Metcalf, J.; Codd, G.; Meriluoto, J. First observation of cylindrospermopsin in Anabaena lapponica isolated from the boreal environment (Finland). Environ. Toxicol. 2006, 21, 552-560.

88. Sinha, R.; Pearson, L.; Davis, T.; Burford, M.; Orr, P.; Neilan, B. Increased incidence of Cylindrospermopsis raciborskii in temperate zones, is climate change responsible? Water Res. 2012, 46, 1408-1419.

89. Kinnear, S. Cylindrospermopsin: A decade of progress on bioaccumulation research. Mar. Drugs 2010, 8, 542-564.

90. Banker, R.; Carmeli, S.; Werman, M.; Teltsch, B.; Porat, R.; Sukenik, A. Uracil moiety is required for toxicity of the cyanobacterial hepatotoxin cylindrospermopsin. J. Toxicol. Environ. Health Part A 2001, 62, 281-288.

91. Banker, R.; Teltsch, B.; Sukenik, A.; Carmeli, S. 7-Epicylindrospermopsin, a toxic minor metabolite of the cyanobacterium Aphanizomenon ovalisporum from Lake Kinneret, Israel. J. Nat. Prod. 2000, 63, 387-389.

92. Li, R.; Carmichael, W.W.; Brittain, S.; Eaglesham, G.K.; Shaw, G.R.; Liu, Y.; Watanabe, M.M. First report of the cyanotoxins cylindrospermopsin and deoxycylindrospermopsin from Raphidiopsis curvata (Cyanobacteria). J. Phycol. 2001, 37, 1121-1126.

93. Briand, J.-F.; Jacquet, S.; Bernard, C.; Humbert, J.-F. Health hazards for terrestrial vertebrates from toxic cyanobacteria in surface water ecosystems. Vet. Res. 2003, 34, 361-377.

94. Chiswell, R.K.; Shaw, G.R.; Eaglesham, G.; Smith, M.J.; Norris, R.L.; Seawright, A.A.; Moore, M.R. Stability of cylindrospermopsin, the toxin from the cyanobacterium, Cylindrospermopsis raciborskii: Effect of $\mathrm{pH}$, temperature, and sunlight on decomposition. Environ. Toxicol. 1999, 14, 155-161.

95. Wormer, L.; Cirés, S.; Carrasco, D.; Quesada, A. Cylindrospermopsin is not degraded by co-occurring natural bacterial communities during a 40-day study. Harmful Algae 2008, 7, 206-213.

96. Jiang, Y.; Xiao, P.; Yu, G.; Sano, T.; Pan, Q.; Li, R. Molecular basis and phylogenetic implications of deoxycylindrospermopsin biosynthesis in the cyanobacterium Raphidiopsis curvata. Appl. Environ. Microbiol. 2012, 78, 2256-2263.

97. Runnegar, M.T.; Xie, C.; Snider, B.B.; Wallace, G.A.; Weinreb, S.M.; Kuhlenkamp, J. In vitro hepatotoxicity of the cyanobacterial alkaloid cylindrospermopsin and related synthetic analogues. Toxicol. Sci. 2002, 67, 81-87. 
98. Humpage, A.R.; Fontaine, F.; Froscio, S.; Burcham, P.; Falconer, I.R. Cylindrospermopsin genotoxicity and cytotoxicity: Role of cytochrome P-450 and oxidative stress. J. Toxicol. Environ. Health Part A 2005, 68, 739-753.

99. Froscio, S.M.; Humpage, A.R.; Burcham, P.C.; Falconer, I.R. Cylindrospermopsin induced protein synthesis inhibition and its dissociation from acute toxicity in mouse hepatocytes. Environ. Toxicol. 2003, 18, 243-251.

100. Runnegar, M.T.; Kong, S.-M.; Zhong, Y.-Z.; Ge, J.-L.; Lu, S.C. The role of glutathione in the toxicity of a novel cyanobacterial alkaloid cylindrospermopsin in cultured rat hepatocytes. Biochem. Biophys. Res. Commun. 1994, 201, 235-241.

101. Runnegar, M.T.; Kong, S.-M.; Zhong, Y.-Z.; Lu, S.C. Inhibition of reduced glutathione synthesis by cyanobacterial alkaloid cylindrospermopsin in cultured rat hepatocytes. Biochem. Pharmacol. 1995, 49, 219-225.

102. Bernard, C.; Harvey, M.; Briand, J.; Biré, R.; Krys, S.; Fontaine, J. Toxicological comparison of diverse Cylindrospermopsis raciborskii strains: Evidence of liver damage caused by a French C. raciborskii strain. Environ. Toxicol. 2003, 18, 176-186.

103. Falconer, I.R.; Humpage, A.R. Preliminary evidence for in vivo tumour initiation by oral administration of extracts of the blue green alga Cylindrospermopsis raciborskii containing the toxin cylindrospermopsin. Environ. Toxicol. 2001, 16, 192-195.

104. Rogers, E.; Zehr, R.; Gage, M.; Humpage, A.R.; Falconer, I.R.; Marr, M.; Chernoff, N. The cyanobacterial toxin, cylindrospermopsin, induces fetal toxicity in the mouse after exposure late in gestation. Toxicon 2007, 49, 855-864.

105. Saker, M.; Neilan, B.; Griffiths, D. Two morphological forms of Cylindrospermopsis raciborskii (cyanobacteria) isolated from Solomon Dam, Palm Island, Queensland. J. Phycol. 1999, 35, 599-606.

106. Byth, S. Palm Island mystery disease. Med. J. Aust. 1980, 2, 40-42.

107. Stuken, A.; Jakobsen, K. The cylindrospermopsin gene cluster of Aphanizomenon sp. strain 10E6: Organization and recombination. Microbiology 2010, 156, 2438-2451.

108. Mihali, T.K.; Kellmann, R.; Muenchhoff, J.; Barrow, K.D.; Neilan, B.A. Characterization of the gene cluster responsible for cylindrospermopsin biosynthesis. Appl. Environ. Microbiol. 2008, 74, 716-722.

109. Muenchhoff, J.; Siddiqui, K.S.; Poljak, A.; Raftery, M.J.; Barrow, K.D.; Neilan, B.A. A novel prokaryotic L-arginine:glycine amidinotransferase is involved in cylindrospermopsin biosynthesis. FEBS J. 2010, 277, 3844-3860.

110. Shalev-Malul, G.; Lieman-Hurwitz, J.; Viner-Mozzini, Y.; Sukenik, A.; Gaathon, A.; Lebendiker, M.; Kaplan, A. An AbrB-like protein might be involved in the regulation of cylindrospermopsin production by Aphanizomenon ovalisporum. Environ. Microbiol. 2008, 10, 988-999.

111. Davis, T.W.; Orr, P.T.; Boyer, G.L.; Burford, M.A. Investigating the production and release of cylindrospermopsin and deoxy-cylindrospermopsin by Cylindrospermopsis raciborskii over a natural growth cycle. Harmful Algae 2014, 31, 18-25. 
112. Saker, M.L.; Neilan, B.A. Varied diazotrophies, morphologies, and toxicities of genetically similar isolates of Cylindrospermopsis raciborskii (nostocales, cyanophyceae) from Northern Australia. Appl. Environ. Microbiol. 2001, 67, 1839-1845.

113. Stucken, K. Physiogenomics of Cylindrospermopsis raciborskii and Raphidiopsis brookii with Emphasis on Cyanobacterial Evolution, Nitrogen Control and Toxin Biosynthesis. In Faculty of Biology and Chemistry; University of Bremen: Bremen, Germany, 2010; p. 222.

114. Bacsi, I.; Vasas, G.; Suranyi, G.; M-Hamvas, M.; Mathe, C.; Toth, E.; Grigorszky, I.; Gaspar, A.; Toth, S.; Borbely, G. Alteration of cylindrospermopsin production in sulfate- or phosphate-starved cyanobacterium Aphanizomenon ovalisporum. FEMS Microbiol. Lett. 2006, 259, 303-310.

115. Bar-Yosef, Y.; Sukenik, A.; Hadas, O.; Viner-Mozzini, Y.; Kaplan, A. Enslavement in the water body by toxic Aphanizomenon ovalisporum, inducing alkaline phosphatase in phytoplanktons. Curr. Biol. 2010, 20, 1557-1561.

116. Burford, M.A.; Davis, T.W.; Orr, P.T.; Sinha, R.; Willis, A.; Neilan, B.A. Nutrient-related changes in the toxicity of field blooms of the cyanobacterium, Cylindrospermopsis raciborskii. FEMS Microbiol. Ecol. 2014, doi:10.1111/1574-6941.12341.

117. Orr, P.T.; Rasmussen, J.P.; Burford, M.A.; Eaglesham, G.K.; Lennox, S.M. Evaluation of quantitative real-time PCR to characterise spatial and temporal variations in cyanobacteria, Cylindrospermopsis raciborskii (Woloszynska) Seenaya et Subba Raju and cylindrospermopsin concentrations in three subtropical Australian reservoirs. Harmful Algae 2010, 9, 243-254.

118. Mohamed, Z.A.; Al-Shehri, A.M. Assessment of cylindrospermopsin toxin in an arid Saudi lake containing dense cyanobacterial bloom. Environ. Monit. Assess. 2013, 185, 2157-2166.

119. Dyble, J.; Tester, P.A.; Litaker, R.W. Effects of light intensity on cylindrospermopsin production in the cyanobacterial HAB species Cylindrospermopsis raciborskii. Afr. J. Mar. Sci. 2006, 28, 309-312.

120. Bormans, M.; Lengronne, M.; Brient, L.; Duval, C. Cylindrospermopsin accumulation and release by the benthic cyanobacterium Oscillatoria sp. PCC 6506 under different light conditions and growth phases. Bull. Environ. Contam. Toxicol. 2014, 92, 243-247.

121. Wu, Z.; Shi, J.; Yang, S. The effect of pyrogallic acid on growth, oxidative stress, and gene expression in Cylindrospermopsis raciborskii (Cyanobacteria). Ecotoxicology 2013, 22, 271-278.

122. Cadel-Six, S.; Iteman, I.; Peyraud-Thomas, C.; Mann, S.; Ploux, O.; Mejean, A. Identification of a polyketide synthase coding sequence specific for anatoxin-a-producing Oscillatoria cyanobacteria. Appl. Environ. Microbiol. 2009, 75, 4909-4912.

123. Sivonen, K.; Jones, G. Cyanobacterial Toxins. In Toxic Cyanobacteria in Water; Chorus, I., Bartram, J., Eds.; WHO E \& FN Spon Publishers: London, UK, 1999.

124. Osswald, J.; Rellan, S.; Gago, A.; Vasconcelos, V. Toxicology and detection methods of the alkaloid neurotoxin produced by cyanobacteria, anatoxin-a. Environ. Int. 2007, 33, 1070-1089.

125. Carmichael, W.; Gorham, P.; Biggs, D. Two laboratory case studies on the oral toxicity to calves of the freshwater cyanophyte (blue-green alga) Anabaena flos-aquae NRC-44-1. Can. Vet. J. 1977, 18, 71-75.

126. Kaminski, A.; Bober, B.; Lechowski, Z.; Bialczyk, J. Determination of anatoxin-a stability under certain abiotic factors. Harmful Algae 2013, 28, 83-87.

127. Carmichael, N. The toxins of cyanobacteria. Sci. Am. 1994, 270, 78-86. 
128. Wood, S.A.; Selwood, A.I.; Rueckert, A.; Holland, P.T.; Milne, J.R.; Smith, K.F.; Smits, B.; Watts, L.F.; Cary, C.S. First report of homoanatoxin-a and associated dog neurotoxicosis in New Zealand. Toxicon 2007, 50, 292-301.

129. Henriksen, P.; Carmichael, W.W.; An, J.; Moestrup, O. Detection of an anatoxin-a(s)-like anticholinesterase in natural blooms and cultures of cyanobacteria/blue-green algae from Danish lakes and in the stomach contents of poisoned birds. Toxicon 1997, 35, 901-913.

130. Edwards, C.; Beattie, K.A.; Scrimgeour, C.M.; Codd, G.A. Identification of anatoxin-A in benthic cyanobacteria (blue-green algae) and in associated dog poisonings at Loch Insh, Scotland. Toxicon 1992, 30, 1165-1175.

131. Duy, T.N.; Lam, P.K.; Shaw, G.R.; Connell, D.W. Toxicology and risk assessment of freshwater cyanobacterial (blue-green algal) toxins in water. Rev. Environ. Contam. Toxicol. 2000, 163, 113-185.

132. Merel, S.; Clement, M.; Thomas, O. State of the art on cyanotoxins in water and their behaviour towards chlorine. Toxicon 2010, 55, 677-691.

133. Sanchez, J.A.; Otero, P.; Alfonso, A.; Ramos, V.; Vasconcelos, V.; Araoz, R.; Molgo, J.; Vieytes, M.R.; Botana, L.M. Detection of anatoxin-a and three analogs in Anabaena spp. cultures: New fluorescence polarization assay and toxin profile by LC-MS/MS. Toxins 2014, 6, 402-415.

134. Rantala-Ylinen, A.; Kana, S.; Wang, H.; Rouhiainen, L.; Wahlsten, M.; Rizzi, E.; Berg, K.; Gugger, M.; Sivonen, K. Anatoxin-a synthetase gene cluster of the cyanobacterium Anabaena sp. strain 37 and molecular methods to detect potential producers. Appl. Environ. Microbiol. 2011, 77, 7271-7278.

135. Méjean, A.; Mann, S.; Maldiney, T.; Vassiliadis, G.; Lequin, O.; Ploux, O. Evidence that biosynthesis of the neurotoxic alkaloids anatoxin-a and homoanatoxin-a in the cyanobacterium Oscillatoria PCC 6506 occurs on a modular polyketide synthase initiated by L-proline. J. Am. Chem. Soc. 2009, 131, 7512-7513.

136. Peary, J.A.; Gorham, P.R. Influence of light and temperature on growth and toxin production by Anabaena flos-aquae. J. Phycol. 1966, 2, 1-3.

137. Gupta, N.; Bhaskar, A.S.B.; Rao, P.V.L. Growth characteristics and toxin production in batch cultures of Anabaena flos-aquae: Effects of culture media and duration. World J. Microbiol. Biotechnol. 2002, 18, 29-35.

138. Rapala, J.; Sivonen, K.; Luukkainen, R.; Niemelä, S. Anatoxin-a concentration in Anabaena and Aphanizomenon under different environmental conditions and comparison of growth by toxic and non-toxic Anabaena-strains-A laboratory study. J. Appl. Phycol. 1993, 5, 581-591.

139. Bumke-Vogt, C.; Mailahn, W.; Rotard, W.; Chorus, I. A highly sensitive analytical method for the neurotoxin anatoxin-a, using GC-ECD, and first application to laboratory cultures. Phycologia 1996, 35, 51-61.

140. Rapala, J.; Sivonen, K. Assessment of environmental conditions that favor hepatotoxic and neurotoxic Anabaena spp. strains cultured under light limitation at different temperatures. Microb. Ecol. 1998, 36, 181-192.

141. Araoz, R.; Nghiem, H.O.; Rippka, R.; Palibroda, N.; de Marsac, N.T.; Herdman, M. Neurotoxins in axenic oscillatorian cyanobacteria: Coexistence of anatoxin-a and homoanatoxin-a determined by ligand-binding assay and GC/MS. Microbiology 2005, 151, 1263-1273. 
142. Kearns, K.D.; Hunter, M.D. Green algal extracellular products regulate antialgal toxin production in a cyanobacterium. Environ. Microbiol. 2000, 2, 291-297.

143. Wiese, M.; Dagostino, P.M.; Mihali, T.K.; Moffitt, M.C.; Neilan, B.A. Neurotoxic alkaloids: Saxitoxin and its analogs. Mar. Drugs 2010, 8, 2185-2211.

144. Strichartz, G. Structural determinants of the affinity of saxitoxin for neuronal sodium channels. Electrophysiological studies on frog peripheral nerve. J. Gen. Physiol. 1984, 84, 281-305.

145. Wang, J.; Salata, J.J.; Bennett, P.B. Saxitoxin is a gating modifier of HERG $\mathrm{K}^{+}$channels. J. Gen. Physiol. 2003, 121, 583-598.

146. Su, Z.; Sheets, M.; Ishida, H.; Li, F.; Barry, W.H. Saxitoxin blocks L-type ICa. J. Pharmacol. Exp. Ther. 2004, 308, 324-329.

147. Nicholson, B.; Shaw, G.R.; Morrall, J.; Senogles, P.; Woods, T.; Papageorgiou, J.; Kapralos, C.; Wickramasinghe, W.; Davis, B.; Eaglesham, G. Chlorination for degrading saxitoxins (paralytic shellfish poisons) in water. Environ. Technol. 2003, 24, 1341-1348.

148. Jones, G.J.; Negri, A.P. Persistence and degradation of cyanobacterial paralytic shellfish poisons (PSPs) in freshwaters. Water Res. 1997, 31, 525-533.

149. Kellmann, R.; Mihali, T.; Jeon, Y.; Pickford, R.; Pomati, F.; Neilan, B. Biosynthetic intermediate analysis and functional homology reveal a saxitoxin gene cluster in cyanobacteria. Appl. Environ. Microbiol. 2008, 74, 4044-4053.

150. Stuken, A.; Campbell, R.; Quesada, A.; Sukenik, A.; Dadheech, P.; Wiedner, C. Genetic and morphologic characterization of four putative cylindrospermopsin producing species of the cyanobacterial genera Anabaena and Aphanizomenon. J. Plankton Res. 2009, 31, 465-480.

151. Soto-Liebe, K.; Murillo, A.A.; Krock, B.; Stucken, K.; Fuentes-Valdes, J.J.; Trefault, N.; Cembella, A.; Vasquez, M. Reassessment of the toxin profile of Cylindrospermopsis raciborskii $\mathrm{T} 3$ and function of putative sulfotransferases in synthesis of sulfated and sulfonated PSP toxins. Toxicon 2010, 56, 1350-1361.

152. Plominsky, Á.M.; Soto-Liebe, K.; Vásquez, M. Optimization of 2D-PAGE protocols for proteomic analysis of two nonaxenic toxin-producing freshwater cyanobacteria: Cylindrospermopsis raciborskii and Raphidiopsis sp. Lett. Appl. Microbiol. 2009, 49, 332-337.

153. Tsuchiya, S.; Cho, Y.; Konoki, K.; Nagasawa, K.; Oshima, Y.; Yotsu-Yamashita, M. Synthesis and identification of proposed biosynthetic intermediates of saxitoxin in the cyanobacterium Anabaena circinalis (TA04) and the dinoflagellate Alexandrium tamarense (Axat-2). Org. Biomol. Chem. 2014, 12, 3016-3020.

154. Mihali, T.; Kellmann, R.; Neilan, B. Characterisation of the paralytic shellfish toxin biosynthesis gene clusters in Anabaena circinalis AWQC131C and Aphanizomenon sp. NH-5. BMC Biochem. 2009, 10, 8:1-8:13.

155. Chislock, M.F.; Sharp, K.L.; Wilson, A.E. Cylindrospermopsis raciborskii dominates under very low and high nitrogen-to-phosphorus ratios. Water Res. 2014, 49, 207-214.

156. Yunes, J.S.; de la Rocha, S.; Giroldo, D.; Silveira, S.B.D.; Comin, R.; Bicho, M.D.S.; Melcher, S.S.; Sant'anna, C.L.; Vieira, A.A.H. Release of carbohydrates and proteins by a subtropical strain of Raphidiopsis brookii (cyanobacteria) able to produce saxitoxin at three nitrate concentrations. J. Phycol. 2009, 45, 585-591. 
157. Kellmann, R.; Neilan, B.A. Biochemical characterization paralytic shellfish toxin biosynthesis in vitro. J. Phycol. 2007, 43, 497-508.

158. Carneiro, R.L.; Santos, M.E.V.D.; Pacheco, A.B.F.; Azevedo, S.M.F.D.O.E. Effects of light intensity and light quality on growth and circadian rhythm of saxitoxins production in Cylindrospermopsis raciborskii (Cyanobacteria). J. Plankton Res. 2009, 31, 481-488.

159. Castro, D.; Vera, D.; Lagos, N.; Garcia, C.; Vasquez, M. The effect of temperature on growth and production of paralytic shellfish poisoning toxins by the cyanobacterium Cylindrospermopsis raciborskii C10. Toxicon 2004, 44, 483-489.

160. Dias, E.; Pereira, P.; Franca, S. Production of paralytic shellfish toxin Aphanizomenon sp. LMECYA 31 (Cyanobacteria). J. Phycol. 2002, 38, 705-712.

161. Pomati, F.; Rossetti, C.; Manarolla, G.; Burns, B.P.; Neilan, B.A. Interactions between intracellular $\mathrm{Na}^{+}$levels and saxitoxin production in Cylindrospermopsis raciborskii T3. Microbiology 2004, 150, 455-461.

(C) 2014 by the authors; licensee MDPI, Basel, Switzerland. This article is an open access article distributed under the terms and conditions of the Creative Commons Attribution license (http://creativecommons.org/licenses/by/3.0/). 